This report was prepared as an account of work sponsored by the United States Government. Neither the United States nor the United States Atomic Energy Conmission, nor any of their employees, nor any of their contractors, subcontractors, or their employees, makes any warranty, express or implied, or assumes any legal liability or responsibility for the accuracy, completeness or usefulness of any information, apparatus, product or process disciosed, or represents that its use would not infringe privately owned rights.

\title{
TRITIUM DISTRIBUTION IN HIGH POWER ZIRCALOY FUEL ELEMENTS
}

L. N. Grossman and J. O. Hegland

Approved:

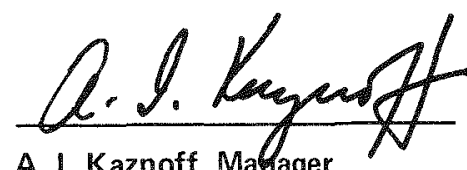

A. I. Kaznoff, Mahager

Metallurgy and Ceramics

GEAP. 12205

AEC Research and

Development Report

June 1971

Prepared for the

United States Atomic Energy Commission

Contract AT(04-3)-189

Project Agreement 41

Printed in U.S. A. Available from the

Clearing House for Federal Scientific and Technical Information

National Bureau of Standards, U. S. Department of Commerce

Price: $\$ 3.00$ per copy; Microfiche $\$ 0.65$

$3450-N L-43$

125-DAC/mea-6/71

NUCLEONICS LABORATORY - GENERAL ELECTRIC COMPANY

VALLECITOS NUCLEAR CENTER, PLEASANTON, CALIFORNIA, 94566

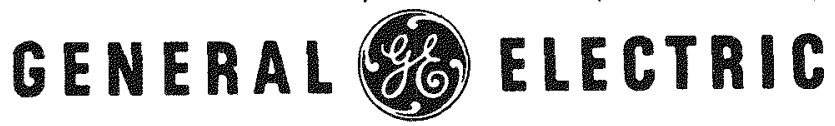




\section{DISCLAIMER}

This report was prepared as an account of work sponsored by an agency of the United States Government. Neither the United States Government nor any agency Thereof, nor any of their employees, makes any warranty, express or implied, or assumes any legal liability or responsibility for the accuracy, completeness, or usefulness of any information, apparatus, product, or process disclosed, or represents that its use would not infringe privately owned rights. Reference herein to any specific commercial product, process, or service by trade name, trademark, manufacturer, or otherwise does not necessarily constitute or imply its endorsement, recommendation, or favoring by the United States Government or any agency thereof. The views and opinions of authors expressed herein do not necessarily state or reflect those of the United States Government or any agency thereof. 


\section{DISCLAIMER}

Portions of this document may be illegible in electronic image products. Images are produced from the best available original document. 


\section{LEGAL NOTICE}

This report was prepared as an account of work sponsored by the United States Government. Neither the United States nor the United States Atomic Energy Commission, nor any of their employees, nor any of their contractors, subcontractors, or their employees, makes any warranty, express or implied, or assumes any legal liability or responsibility for the accuracy, completeness or usefulness of any information, apparatus, product or process disclosed, or represents that its use would not infringe privately owned rights. 


\title{
CONTENTS
}

\begin{abstract}
Page
ABSTRACT . . . . . . . . . . . . . . . . . . . . . . . . . . . . . . 1

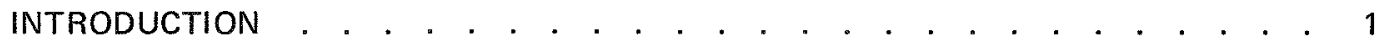

FUEL ELEMENT HISTORY . . . . . . . . . . . . . . . . . . . . . . . . . . . 1

EXPERIMENTAL TECHNIQUES . . . . . . . . . . . . . . . . . . . . . . 4

EXPERIMENTAL RESULTS . . . . . . . . . . . . . . . . . . . . . . . 5

DISCUSSION OF RESULTS . . . . . . . . . . . . . . . . . . . . . . . . . . 10

CONCLUSIONS . . . . . . . . . . . . . . . . . . . . . . . . . . . . 11

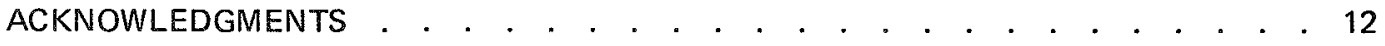

REFERENCES . . . . . . . . . . . . . . . . . . . . . . . . . . . . . . . . . 12

APPENDIX A. . . . . . . . . . . . . . . . . . . . . . . . . 32

APPENDIX B . . . . . . . . . . . . . . . . . . . . . . . . . 35
\end{abstract}

\section{TABLES}

No.

1. Pre-Irradiation Chemical and Mechanical Analyses of Rod 12FV . . . . . . . . 3

2. Final Cycle Power Ratings for Rod $12 \mathrm{FV}$. . . . . . . . . . . . . . . . . . 3

3. Pre-Irradiation Chemical and Mechanical Analyses of Rod-CP-206 . . . . . . . . 4

4. Gas Chromatographic Analysis of CP-206 Cladding Offgas . . . . . . . . . . . 6

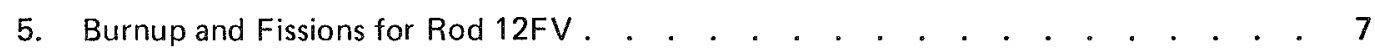

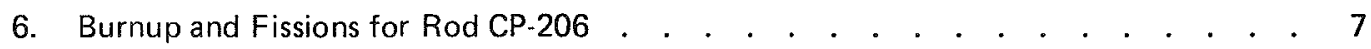

7. Experimental Data for Tritium in Cladding . . . . . . . . . . . . . . 8

8. Experimental Data for Tritium in Fuel . . . . . . . . . . . . . . . . . . . . . 9

9. Gas Compositions by Mass Spectrometry . . . . . . . . . . . . . . . . . . 9

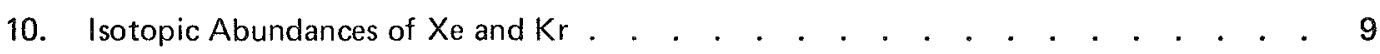

11. Experimental Tritium Partitioning Summary . . . . . . . . . . . . . . . 11 


\section{ILLUSTRATIONS}

No.

1. Twin Distillation Apparati for Recovery of Tritium from Fuel . . . . . . . . . 14

2a. Neutron Radiography of Rod CP-206 . . . . . . . . . . . . . . . . . 15

2b. Neutron Radiography of Rod CP-206 . . . . . . . . . . . . . . . . . . . 16

3. Neutron Radiography of Rod $12 \mathrm{FV}$. . . . . . . . . . . . . . . . . . 17

4. Gamma Activity Profiles for CP-206 . . . . . . . . . . . . . . . . 18

5. Gamma Activity Profile for $12 \mathrm{FV}$. . . . . . . . . . . . . . . . . 19

6. Burnup, Tritium, and Hydrogen Experimental Values Along Rod CP-206 . . . . . 20

7. Burnup, Tritium, and Hydrogen Experimental Values Along Rod 12FV . . . . . 21

8. Longitudinal Macrosection from Rod 12FV, Top of Freezing Void (Segment O) . . 22

9. Longitudinal Macrosection from Rod CP-206, Segment R . . . . . . . . . . 23

10. Transverse Section Macrographs . . . . . . . . . . . . . . . . . . . . . 24

11. Fuel Microstructures . . . . . . . . . . . . . . . . . . . . . . . . . . . 25

12. Typical Cladding Microstructures Showing Hydrides . . . . . . . . . . . . 26

13. Microstructures Showing Hydride at Cladding Outside Diameter and Crud Layers . . 27

14. Tritium Distribution in Rod CP-206 . . . . . . . . . . . . . . . . . . . . . . . . . 28

15. Tritium Distribution in Rod $12 \mathrm{FV}$. . . . . . . . . . . . . . . . . . . . . . . 29

16. Tritium Release vs. Linear Power . . . . . . . . . . . . . . . . . . 30

17. Tritium in Fuel vs. Burnup . . . . . . . . . . . . . . . . . . . . . 31 


\title{
TRITIUM DISTRIBUTION IN HIIGH POWER FUEL ELEMENTS
}

\author{
L. N. Grossman and J. O. Hegland
}

\begin{abstract}
Tritium distributions have been determined for the fuel and cladding of two $\sim 1 / 2$ inch diameter Zircaloy-2-clad $\mathrm{UO}_{2}$ fuel elements. Rod CP-206 obtained an average burnup of $12,000 \mathrm{MWd} / \mathrm{Te}$ at an average maximum linear power of $17.6 \mathrm{~kW} / \mathrm{ft} ; 75 \%$ of the tritium was released from the fuel. Rod $12 \mathrm{FV}$ obtained average burnup of $21,000 \mathrm{MWd} / \mathrm{Te}$ at an average maximum linear power of $31.4 \mathrm{~kW} / \mathrm{ft}$; $96 \%$ of the tritium was released from the fuel. $A$ correlation between tritium release and power density was obtained. The results of neutron radiography, ceramographic examinations, gamma activity profiles, burnup and fission analyses, puncture gas analyses (including fission gas isotopes) and vacuum outgas analyses of the claddings are also given. Tritium was distributed nonuniformly in the cladding; hydrogen, from general corrosion was uniformly distributed. Thermal diffusion of tritium toward fuel-free regions was indicated in the cladding of Rod $12 \mathrm{FV}$ which was irradiated in a pressurized water loop with larger lineal thermal gradients along the cladding.
\end{abstract}

\section{INTRODUCTION}

Essentially all the radioactive products generated in the fuel of a nuclear power plant are transferred to the fuel reprocessing plant. For Zircaloy-clad fuels, the tritium produced from ternary fission 1 and other sources is expected to be divided between the fuel where it is born and the cladding where it is chemically combined ${ }^{2}$ Current reprocessing plants, ${ }^{3}$ as exemplified by the General Electric Company Midwest Fuel Recovery Plant (near Morris, Illinois), dispose of the cladding by permanent underwater burial in a stainless-steel-lined concrete container. The vault design permits retrieval of the scrap for off-site disposal at some future time, if desired. Alternate disposal of the cladding under consideration is concrete grouting of the entire vault.

During reprocessing, ${ }^{3}$ tritium which was received in the fuel ends up in the purified process water. Tritium is the only significant radioisotope in that water after purification. Since the amount of process water to be disposed of is relatively small, it has been considered practical to release it in the ventilation air after dilution through use of a 300 -foot tall stack. There is flexibility in the hold-up time (up to several months) and release rate of the purified process water, thus allowing disposal during more favorable meterological conditions.

The division between that tritium which is buried with the cladding and that which is retained in the purified process water is the division between cladding and fuel tritium. For low and moderate power-rated fuel rods, it has been shown ${ }^{4-6}$ that roughly $10 \%$ of the tritium inventory migrates to and is inerted in the cladding, while about $90 \%$ of the tritium remains in the oxide fuel. For fuel rods which receive higher power ratings (and higher fuel temperatures) than those previously reported, ${ }^{4-6}$ it was anticipated that a larger fraction of the tritium should be inerted in the cladding and destined for burial. Similarly, a smaller fraction of tritium should remain in the fuel and therefore destined for the process water during reprocessing.

The objective of the present study was to measure the partitioning of tritium between the fuel and the cladding (and the gas phase) of a high power-rated rod and a rod typical of current power reactor design.

\section{FUEL ELEMENT HISTORY}

Two fuel rods meeting the objectives of this study were selected. Rod 12FV of Assembly EX-12A had been irradiated at a burnup-average maximum linear power density of $31.4 \mathrm{~kW} / \mathrm{ft}$ (peak at $49.7 \mathrm{~kW} / \mathrm{ft}$ ) in the General Electric Test Reactor. The average burnup obtained was 21,000 MWd/Te; the peak burnup was 23,500 MWd/Te. Rod CP-206 of Bundle D-50 was irradiated to a burnup-average maximum linear power density of $17.6 \mathrm{~kW} / \mathrm{ft}$ (peak $22.3 \mathrm{~kW} / \mathrm{ft}$ ) in the Big Rock Point Reactor. Rod CP-206 obtained an average burnup of $12,000 \mathrm{MWd} / \mathrm{Te}$ with a peak of $15,500 \mathrm{MWd} / \mathrm{Te}$. 


\section{ROD 12FV}

Rod $12 \mathrm{FV}$ was built and irradiated as part of the High Performance $\mathrm{UO}_{2}$ Program. ${ }^{7}$ The objective of the program, initiated in 1961, was to explore systematically the feasibility and limitations of $\mathrm{UO}_{2}$ fuel elements operated for extended periods of time with central melting. Assembly EX-12A was the final assembly of this program and achieved sustained maximum heat flux levels in excess of one million Btu/h- $\mathrm{ft}^{2}$. It was irradiated during GETR Cycles 54 through 58 in mid-1964. Rod 12FV had been irradiated to a maximum of about $11,000 \mathrm{MWd} / \mathrm{Te}$ as part of a previous assembly, EPW-12V during GETR Cycles 47 through 52 in late 1963. Both assemblies were irradiated in the Pressurized Water Loop (PWL) of the General Electric Test Reactor (GETR). The PWL is a general-purpose in-core loop with water as the primary coolant at about $350^{\circ} \mathrm{F}$, and a hydrogen over-pressure of $1200 \mathrm{psi}$. The peak thermal flux in the loop is about $3 \times 10^{14} \mathrm{nv}$, which can produce heat fluxes up to $15 \times 10^{6} \mathrm{Btu} / \mathrm{h} \cdot \mathrm{ft}^{2}\left(470 \mathrm{~W} / \mathrm{cm}^{2}\right)$ in the fuel elements.

Rod $12 \mathrm{FV}$ was made of Zircaloy-2 cladding and $\mathrm{UO}_{2}$ fuel. The Zircaloy-2 chemical and mechanical analyses are shown in Table 1. The cladding was nominally $1.435 \mathrm{~cm}(0.565 \mathrm{in.})$ o.d. and $0.076 \mathrm{~cm}(0.030 \mathrm{in.})$ thick. The Zircaloy-2 was steam autoclaved at $750^{\circ} \mathrm{F}$, resulting in a thin $(\sim 1 / 2 \mu \mathrm{m})$ adherent black oxide layer on all surfaces. The fuel was vibratory-compacted $\mathrm{UO}_{2}$ with the chemical analysis shown in Table 1. The as-received arc-fused $\mathrm{UO}_{2}$ powder (from Spencer Chemical Co.) was heated for $4 \mathrm{~h}$ in wet hydrogen at $1650^{\circ} \mathrm{C}$ to assure an O-to-U ratio near 2.00 . The powder was then seived and blended to give a particle size distribution for a high compaction efficiency. The fuel was loaded to $83 \%$ of theoretical density over a column length of $76 \mathrm{~cm}(29.9 \mathrm{in}$.$) . A total weight of 889 \mathrm{~g} \mathrm{UO}_{2}$ was used. The over-all fuel rod length was $99.1 \mathrm{~cm}(39.0 \mathrm{in}$.). The free volume of the rod was filled with helium at atmospheric pressure before the final seal weld was made on the end plug. Before sealing of the fuel element, it was vacuum outgassed at $480^{\circ} \mathrm{C}$ to remove moisture.

Rod 12FV received 5501 hours at full power and reached a final maximum burnup of 23,500 MWd/Te, The time-average maximum power rating over its irradiation history was therefore $31.6 \mathrm{~kW} / \mathrm{ft}$. The average power ratings during the final four GETR cycles were significantly lower than the earlier ratings and are given in Table 2. The burnup-average maximum power rating ${ }^{*}$ over the full power history of Rod $12 \mathrm{FV}$ is $31.4 \mathrm{~kW} / \mathrm{ft}$.

\section{ROD CP-206}

Rod CP-206 was fabricated and irradiated as part of the Power Reactor High Performance $\mathrm{UO}_{2}$ Program 8 initiated in 1966. The Power Reactor Program was a continuation of the High Performance $\mathrm{UO}_{2}$ Program 7 begun in 1961. The objective of the Power Reactor Program was to operate $\mathrm{UO}_{2}$ fuel elements with varying degrees of central melting at rated power to high burnup in a commercial power reactor core. The Power Reactor Program fuel elements were irradiated in the Big Rock Point (BRP) Reactor, near Charlevoix, Michigan, through the cooperation of Consumers Power Company, a sponsoring party to the Power Reactor Program.

Rod CP-206 was assembled as a component of Bundle D-50, an $8 \times 8$ bundle designed 8 a to operate at "Intermediate" fuel performance with incipient central melting. The cladding was nominally $0.570 \mathrm{in}$. $0 . d . \times 0.035$ inch wall autoclaved Zircaloy-2; the chemical and mechanical analyses are given in Table 3 . The fuel was pelletized $\mathrm{UO}_{2}$ sintered to a nominal $95 \%$ of theoretical density in wet hydrogen at about $1650^{\circ} \mathrm{C}$. The fuel pellets were dished on one end to provide a truncated cone about $5 \%$ of the pellet volume. The pellets were ground to provide a nominal diametral gap of 0.012 inch. The chemical analyses of the pellets are given in Table 3 . The smeared fuel density was approximately $90 \%$ of theoretical density.

The fuel column length in Rod CP-206 was 67.28 inches. The over-all fuel element length was 74.75 inch. Since the fuel column of Rod CP-206 was shorter than the standard BRP fuel rod (because of the larger plenum necessitated by expected higher fission gas release), tantalum strips were placed on the plenum to serve as neutron absorbers to prevent flux peaking in the upper end of the adjacent standard fuel assemblies. The rod was back-filled with $1 \mathrm{~atm}$ He after fuel loading and before welding of the upper end plug.

*Burnup-average power rating is $\frac{(k W / f t) d(b . u .)}{b . u .}$ 
TABLE 1. Pre-irradiation Chemical and Mechanical Analyses* of Rod 12FV

Cladding

Ingot No. 34079, Lot No. 1655

Corrosion Weight Gain 17.7 and $18.0 \mathrm{mg} / \mathrm{dm}^{2}$ in 3 days at $750^{\circ} \mathrm{F}$, 1500 psı steam $\left(399^{\circ} \mathrm{C}, 1.05 \times 10^{6} \mathrm{~kg} / \mathrm{m}^{2}\right)$

Chemical Analysis

\begin{tabular}{|c|c|c|c|c|}
\hline Alloy Elen & nts & $\%$ & & \\
\hline Sn & & 153 & & \\
\hline $\mathrm{Fe}$ & & 0125 & & \\
\hline $\mathrm{Cr}$ & & 0.095 & & \\
\hline $\mathrm{Ni}$ & & 0056 & & \\
\hline $\mathrm{Fe}+\mathrm{Cr}$ & & 0.276 & & \\
\hline Impurity & ppm & & Impurity & ppm \\
\hline Al & 46 & & $\mathrm{Hf}$ & 60 \\
\hline B & 03 & & $\mathrm{Mg}$ & $<10$ \\
\hline c & 148 & & $\mathrm{Mn}$ & $<20$ \\
\hline $\mathrm{Ca}$ & $<20$ & & Mo & $<20$ \\
\hline $\mathrm{Cd}$ & $<025$ & & $\mathrm{Na}$ & $<10$ \\
\hline $\mathrm{Cl}$ & $<20$ & & $\mathrm{~Pb}$ & $<20$ \\
\hline Co & $<5$ & & $\mathrm{SI}$ & 35 \\
\hline $\mathrm{Cu}$ & $<20$ & & $\mathrm{Ti}$ & $<20$ \\
\hline
\end{tabular}

\begin{tabular}{cc} 
Impurity & ppm \\
\cline { 1 - 2 }$V$ & $<20$ \\
$W$ & $<20$ \\
$U$ & 0.28 \\
$H$ & 16 \\
$N$ & 31 \\
O & 1330
\end{tabular}

Room Temperature Longitudinal Mechanical Properties

Ultimate Tensile Strength, $\mathrm{ksi}\left(\mathrm{kg} / \mathrm{m}^{2}\right)$

Yield Strength (0 $2 \%$ offset), $\mathrm{ksi}\left(\mathrm{kg} / \mathrm{m}^{2}\right)$

Elongation in 2 inches, $\%(5 \mathrm{~cm})$

Hardness (Rockwell B)

Grain Size

Flare Test

Burst Test

ASTM-7 $79.2\left(555 \times 10^{6}\right)$

$614\left(43.0 \times 10^{6}\right)$

255

88.5

$330 \%$ and $320 \%$ od expansion at 60 degrees

10,500 psı vield pressure $\left(7.4 \times 10^{6} \mathrm{~kg} / \mathrm{m}^{2}\right)$

8,500 psi burst pressure $\left(595 \times 10^{6} \mathrm{~kg} / \mathrm{m}^{2}\right)$
Fuel

Impurity ppm

$\begin{array}{lr}\mathrm{Al} & 10 \\ \mathrm{Bl} & <2 \\ \mathrm{~B} & <0.2 \\ \mathrm{Cd} & <2 \\ \mathrm{Ca} & 10 \\ \mathrm{Cr} & 10 \\ \mathrm{Co} & <2 \\ \mathrm{Cu} & 1 \\ \mathrm{Fe} & -20 \\ \mathrm{~Pb} & <1 \\ \mathrm{Mg} & 2 \\ \mathrm{Mn} & <10 \\ \mathrm{Mlo} & <3 \\ \mathrm{Si} & 10 \\ \mathrm{Ag} & 5 \\ \mathrm{Na} & <35 \\ \mathrm{Sn} & <1 \\ \mathrm{~V} & <15 \\ \mathrm{Zn} & <50 \\ \mathrm{Ni} & 10 \\ \mathrm{TI} & <10 \\ \mathrm{Ta} & <1 \\ \mathrm{~W} & <1 \\ \mathrm{~N} & 330 \\ \mathrm{C} & 40 \\ & \end{array}$

U.235\% (3.74 \pm 0.04$)$

O-to-U ratıo 2.02

${ }^{*}$ GEAP $-5100-2$, October 1966

TABLE 2. Final Cycle Power Ratıngs * for Rod 12FV

$\begin{array}{lccccc}\text { GETR Cycle } & 54 & 55 & 56 & 57 & 58 \\ \text { Full Power, h } & 425 & 643 & 634 & 607 & 521 \\ \text { Average Burnup (MWd/Te) } & 1620 & 2180 & 2160 & 2160 & 1780 \\ \text { Maximum Linear Power (kW/ft) } & 29.0 & 23.2 & 232 & 22.3 & 23.3\end{array}$

*After GEAP-5100M, corrected for measured burnup 
Heat No. K-1013, 3943, and 370115 (typical)

Corrosion Weight Gain: $17 \mathrm{mg} / \mathrm{dm}^{2}$ in 3 days at $750^{\circ} \mathrm{F}, 1500$ psi steam

$\frac{\text { Fuel }}{\text { Impurity ppm }}$

Chemical Analysis:

\begin{tabular}{|c|c|}
\hline Alloy Elements & $\%$ \\
\hline Sn & 1.5 \\
\hline $\mathrm{Fe}$ & 0.13 \\
\hline $\mathrm{Cr}$ & 0.08 \\
\hline$N_{1}$ & 0.06 \\
\hline $\mathrm{Fe}+\mathrm{Cr}+\mathrm{N}$ & 0.27 \\
\hline
\end{tabular}

\begin{tabular}{|c|c|c|c|}
\hline & & Al & 54 \\
\hline & & $\mathrm{Bi}$ & $<1$ \\
\hline & & $\mathrm{B}$ & 0.3 \\
\hline & & $\mathrm{Ca}$ & $<2$ \\
\hline & & $\mathrm{Cd}$ & $<0.5$ \\
\hline & & $\mathrm{Cr}$ & 24 \\
\hline & & Co & $<2$ \\
\hline & & $\mathrm{Cu}$ & $<1$ \\
\hline & & $\mathrm{Fe}$ & 30 \\
\hline & & $\mathrm{Pb}$ & $<1$ \\
\hline & & $\mathrm{Mg}$ & 2 \\
\hline Impurity & ppm & $\mathrm{Mn}$ & $<2$ \\
\hline$\pi$ & $<20$ & Mo & $<3$ \\
\hline V & $<5$ & $\mathrm{Si}$ & 16 \\
\hline$w$ & $<25$ & $\mathrm{Ag}$ & $<0.1$ \\
\hline U & $<1$ & $\mathrm{Na}$ & $<15$ \\
\hline$H$ & 6 & $\mathrm{Sn}$ & $<1$ \\
\hline$N$ & 30 & V & $<11$ \\
\hline 0 & 1200 & $\mathrm{Zn}$ & $<10$ \\
\hline & & $\mathrm{Ni}$ & 6 \\
\hline & & $\mathrm{Sb}$ & $<2$ \\
\hline & & $N$ & $<5$ \\
\hline & & $\mathrm{c}$ & 4 \\
\hline & & $\mathrm{F}$ & 4 \\
\hline & & $\mathrm{Cl}$ & $<3$ \\
\hline
\end{tabular}

Ultimate Tensile Strength, $\mathrm{ksı}\left(\mathrm{kg} / \mathrm{m}^{2}\right) \quad 92$

Yield Strength $(0.2 \%$ offset $), \mathrm{ksl}\left(\mathrm{kg} / \mathrm{m}^{2}\right) \quad 70$

Elongation in 2 inches, \% 25

Hardness (Rockwell B) 94

U-235\% $5.05 \pm 0.04$

Grain Size.

ASTM-11

Flare TEst: $\quad>15 \%$ of o.d. at 60 degrees

O-to-U ratio 2.016

Burst Test: $\quad 13,000$ psi burst pressure

${ }^{*}$ GEAP-10032, June, 1969

Rod CP-206 was located at an outside face of the $8 \times 8$ Bundle D-50 in position 6 A. The bundle features are described further in Reference 8a. Rod CP-206 received 8544 full-power hours between March 1968 and April 1969. It reached a final maximum burnup of $15,600 \mathrm{MWd} / \mathrm{Te}$. The average burnup of the fuel was $12,000 \mathrm{MWd} / \mathrm{Te}$. The time-average maximum power rating was $16.1 \mathrm{~kW} / \mathrm{ft}$. The rod reached its peak maximum power rating for $384 \mathrm{~h}$ at $22.8 \mathrm{~kW} / \mathrm{ft}$ at approximately $3000 \mathrm{MWd} / \mathrm{Te}$. The burnup-average maximum power rating was $17.6 \mathrm{~kW} / \mathrm{ft}$ with lower ratings received during the final approximate $4000 \mathrm{MWd} / \mathrm{Te}$. The final approximate $1500 \mathrm{MWd} / \mathrm{Te}$ was accumulated at the lowest sustained maximum power rating, $11.4 \mathrm{~kW} / \mathrm{ft}$.

\section{EXPERIMENTAL TECHNIQUES}

Both rods were nondestructively examined by the following established techniques: visual, neutron radiography, gamma scan, ${ }^{9}$ and burnup analysis. 10 For Rod CP-206 two gamma scans were performed, one which recorded all gamma energies (total gamma activity) and one which recorded only those gammas with energies between about 0.55 and $0.7 \mathrm{MeV}$. Twenty mil slits were used in both cases. Rod $12 \mathrm{FV}$ was scanned only in the single channel (0.55- $0.7 \mathrm{MeV}$ ) mode with 62-mil slits. The larger slits were required because of the long decay time undergone by Rod 12FV. The two rods were then punctured and the internal gases collected for fission gas analyses 9,11 and for 
tritium analysis. ${ }^{12}$ The rods were then sectioned into 3-inch segments (for CP-206) and 2-inch segments (for 12FV) according to the instructions given in Appendix A.

Cladding specimens for tritium analysis were cut into approximately $3 / 8$-inch squares and cleaned in nitric acid (to remove $\mathrm{UO}_{2}$ ) and hydrochloric acid (to remove crud from the BRP Rod CP-206) in the Remote Handling Laboratory. The specimens were rinsed in distilled water and dried for transfer to NL-Chemistry for vacuum outgassing. The cladding specimens were vacuum outgassed ${ }^{13}$ for $30 \mathrm{~min}$. at $1300^{\circ} \mathrm{C}$ and the gas collected and its quantity measured. The outgas was then aliquoted and transferred to NL-Ceramic Development for conversion 12 of the HT and $\mathrm{T}_{2}$ to water. The recovered tritiated water aliquot (typically approximately $0.1 \mathrm{ml}$ ) was then rinsed out into about $10 \mathrm{cc}$ of scintillation fluid and analyzed by liquid scintillation counting. 14 Typically one or two further dilutions with scintillation fluid were required to bring the specimen aliquot into optimum counting range. For a few specimens the balance of the vacuum outgas specimen was analyzed by gas chromatography for the species present.

Fuel specimens weighing typically $10 \mathrm{~g}$ were treated in a manner similar to that of Goode and Cox 4 to recover the tritium. The recovery apparati (two were used) are shown in Figure 1, and the instructions for recovery are given in Appendix B. Two recoveries per $8 \mathrm{~h}$ day could be made following those instructions.

Standard specimens were prepared for the cladding and fuel tritium analyses. An $8.83 \mathrm{~g}$ specimen of unirradiated $\mathrm{UO}_{2}$ was dissolved according to the procedure given in Appendix B except $10 \mathrm{cc}$ of certified activity water containing $2.6 \times 10^{7} \mathrm{dpm}\left(1.3 \times 10^{-3} \mu \mathrm{g}\right)$ tritium was added to the dissolved fuel before distillation. Zirconium alloy foil containing tritium was prepared by diluting pure $\mathrm{T}_{2}$ in $\mathrm{H}_{2}$ and then hydriding the alloy until all gas was gettered as indicated by pressure drop. The alloy foil was then chopped and mixed to assure homogeneity of the standard. Unfortunately, a procedural error in standard preparation resulted in about 3 times as much $T$ in the standard as planned and precluded use of the standard as a precision calibration. The standard foil was used to evaluate the reproducibility of the cladding tritium analysis chain.

Ceramographic examinations 12 of one longitudinal and one transverse section of each rod were performed. The longitudinal sections were ground to the axial midpoint and then polished. The transverse sections were etched and photomicrographed at $50 \mathrm{X}$ to determine the grain structure of the fuel. The cladding in all four specimens was etched and photomicrographed at $250 \mathrm{X}$ to show hydride precipitation.

\section{EXPERIMENTAL RESULTS}

\section{NEUTRON RADIOGRAPHY}

Neutron radiographs were obtained using two exposures, to bring out fuel and cladding details, respectively. Figure 2 shows the results for Rod CP-206 and Figure 3 shows the results for Rod 12FV. The figures are folded for convenience in presentation, neutron radiography was performed on the intact rod. The codes used in sectioning are shown to scale along each rod.

\section{GAMMA ACTIVITY AND MAJOR RESULT TABULATION}

The gamma activity profiles of Rod CP-206 are shown in Figure 4. The profile for Rod 12FV is shown in Figure 5. Figures 6 and 7 also show the gamma activity profiles along with the major experimental results. Figures 6 and 7 show the location of the various specimens for tritium, burnup, and ceramographic analyses. A summary of the results of the tritium, burnup, and total outgas are presented in tabular form on the figures.

\section{GAS CHROMATOGRAPHY OF CLADDING OUTGAS}

Table 4 shows the gas chromatographic analyses obtained on the six offgas specimens from the cladding of RodCP-206. The gas chromatographic data are generally reliable to within a few percent. 
TABLE 4. Gas Chromatographic Analysis of CP206 Cladding Otfgas

\begin{tabular}{|c|c|c|c|c|c|c|c|c|c|}
\hline \multirow{2}{*}{$\begin{array}{l}\text { Sample } \\
\text { Location } \\
\end{array}$} & \multirow{2}{*}{$\begin{array}{c}\text { Sample } \\
\text { Weight }(\mathrm{g}) \\
\end{array}$} & \multirow{2}{*}{$\begin{array}{l}\text { Total } \\
\text { Outgas } \\
(\mu / / g) \\
\end{array}$} & \multicolumn{6}{|c|}{ Volume Percent Offgas Composition } & \multirow{2}{*}{$\begin{array}{c}\mathrm{ppm} \\
\mathrm{H}_{2} \\
\end{array}$} \\
\hline & & & $\underline{\mathrm{H}_{2}}$ & $\mathrm{O}_{2}$ & $\mathrm{~N}_{2}$ & $\mathrm{CH}_{4}$ & $\mathrm{co}$ & $\mathrm{CO}_{2}$ & \\
\hline$D$ & 0.462 & 474 & 90.3 & nd & nd & nd & 11.4 & nd & 38 \\
\hline $\mathrm{F}$ & 0.387 & 434 & 79.1 & nd & nd & nd & 20.4 & nd & 30 \\
\hline $\mathrm{H}$ & 0.518 & 359 & 80.6 & nd & nd & nd & 17.8 & nd & 25 \\
\hline$N$ & 0.383 & 401 & 97.9 & nd & nd & nd & 3.2 & nd & 35 \\
\hline $\mathbf{P}$ & 0.490 & 456 & 99.4 & nd & nd & nd & 2.0 & nd & 40 \\
\hline$V$ & 0.361 & 294 & 44.2 & nd & nd & nd & 55.1 & nd & 11 \\
\hline
\end{tabular}

nd $=$ not detected

\section{CERAMOGRAPHIC ANALYSES}

Figures 8 through 13 show the results of ceramographic analyses of the fuel and cladding. Rod 12FV showed evidence of fuel melting over about $70 \%$ of the rod diameter (Figures 10 and 11 ). Small metallic inclusions were seen throughout the outer regions (noncolumnar) of the fuel. The outermost region of the cladding, representing about $10 \%$ of the wall thickness, contained the highest concentration of hydride precipitates (Figure 13). The hydride content in this region of high concentration is estimated to be about $500 \mathrm{ppm}$ hydrogen. Throughout most of the cladding, exclusive of the outside diameter region, the hydride content is estimated to be about $50 \mathrm{ppm}$ (Figure 12).

Rod CP-206 shows no indication of central melting in Figures 9 or 10. The region of grain growth extends over about $55 \%$ the diameter (Figure 11). Small metallic inclusions could be seen in the central regions of the fuel and extended out over about 120 mils from the thermal center. The hydride precipitates were distributed uniformly throughout the cladding (Figures 12 and 13); the hydrogen content of the cladding is estimated at $50 \mathrm{ppm}$. A layer of crud 1-1/2 and 2 mils thick can be seen in Figure 13 with a thin oxide layer beneath it and adherent to the cladding.

\section{BURNUP ANALYSES}

Three burnup specimens were analyzed from each rod. Their positions are indicated in Figures 6 and 7 . The results are given in Table 5 and 6 for Rods $12 \mathrm{FV}$ and CP-206, respectively. The Nd method ${ }^{10}$ for burnup analysis is estimated to be accurate to $\pm 2 \%$; the heavy element method is less accurate.

The total gamma activity profile for Rod CP-206 (Figure 4) was used to scale the burnup values of Table 6 over the full length of the fuel column. Integration of the scaled values along the length resulted in an average burnup figure for the fuel. The burnup values from Table 7 were scaled to the previously published $7 \mathrm{c}$ total gamma activity profile for Rod $12 \mathrm{FV}$, the scaled values were also averaged by integrations. The scaling and averaging procedures resulted in average burnup values of 12,000 MWd/te for Rod CP-206 and $21.000 \mathrm{MWd} / \mathrm{Te}$ for Rod 12FV.

\section{TRITIUM CONTENT OF CLADDING}

Table 7 gives the experimental data obtained from vacuum outgassing of the cladding specimens. One zirconium alloy blank (no tritium) and three alloy standards containing the same level of tritium were also outgassed. Aliquots of the total outgas were taken for conversion to water and counting for tritium. The conversion and counting data are also given in Table 7. Carryover of tritium in the conversion system gave a background of about $10^{5} \mathrm{dpm}$ tritium which shows up on the "Blank" and "Zr-no $T$ " specimens in Table 7; no correction was made for this background. 
TABLE 5. Burnup and Fissions for Rod 12FV

\begin{tabular}{|c|c|c|c|}
\hline & Segment $\mathrm{H}$ & Segment K & Segment $\mathrm{O}$ \\
\hline \multicolumn{4}{|l|}{ Burnup (MWd/Te) } \\
\hline Nd Method & 23,237 & 23,484 & 19,680 \\
\hline Heavy Element Method & 23,255 & 22,797 & 19,457 \\
\hline \multicolumn{4}{|l|}{ Fissions (at. \%) } \\
\hline$U-235$ & 1.74 & 1.72 & 1.55 \\
\hline Pu-239 & 0.50 & 0.48 & 0.33 \\
\hline $\mathrm{Pu}-241$ & 0.03 & 0.03 & 0.02 \\
\hline$U-238$ & 0.15 & 0.15 & 0.13 \\
\hline Total & 2.42 & 2.37 & 2.03 \\
\hline
\end{tabular}

TABLE 6. Burnup and Fissions for Rod CP206

\begin{tabular}{|c|c|c|c|}
\hline & Segment $N$ & Segment $\mathbf{P}$ & Segment $R$ \\
\hline \multicolumn{4}{|l|}{ Burnup (MWd/Te) } \\
\hline Nd Method & 15,561 & 15,530 & 13,166 \\
\hline Heavy Element Method & 16,357 & 16,417 & 14,504 \\
\hline \multicolumn{4}{|l|}{ Fissions (at. \%) } \\
\hline $\mathrm{U}-235$ & 1.45 & 1.45 & 1.30 \\
\hline $\mathrm{Pu}-239$ & 0.13 & 0.14 & 0.105 \\
\hline $\mathrm{Pu}-241$ & 0.004 & 0.004 & 0.003 \\
\hline$U-238$ & 0.12 & 0.12 & 0.11 \\
\hline Total & 1.71 & 1.72 & 1.52 \\
\hline
\end{tabular}

\section{TRITIUM CONTENT OF FUEL}

Table 8 gives the experimental data from dissolution, distillation, and counting of tritium in fuel samples. The "Blank" specimens were pellets of unirradiated $\mathrm{UO}_{2}$ which were dissolved in the Radioactive Handling Laboratory apparatus and carried through the full analytical train. The standard sample showed recovery of $1.11 \times 10^{-3} \mu \mathrm{g}$ tritium $\left(1.3 \times 10^{-3} \mu \mathrm{g}\right.$ tritium added). No corrections for recovery efficiency were added to the data in Table 8.

\section{PUNCTURE GAS ANALYSES}

The two rods were punctured before sectioning and the total gas content measured. Rod CP-206 had a total gas content of $168.7 \mathrm{ml} \mathrm{STP}$ and Rod 12FV contained $568.9 \mathrm{ml}$ (STP). Of these totals, $110.5 \mathrm{ml}$ and $64.55 \mathrm{ml}$ were transferred out of the Remote Handling Operation for analyses. Five analyses were performed: (a) total gas composition by mass spectrometry, (b) isotopic composition of the fission gases $\mathrm{Xe}$ and $\mathrm{Kr}$, (c) precision $\mathrm{Xe}$-to- $\mathrm{Xe}+\mathrm{Kr}$ ratio by mass spectrometry, (d) tritium content of the gas, and (e) total $\mathrm{Xe}+\mathrm{Kr}$ by $\mathrm{Kr}-85$ assay and the data from (b) and (c). The results of the first two analyses are presented in Tables 9 and 10.

The gas compositions in Table 9 are accurate to within $\pm 20 \%$ for major species and order-of-magnitude values for minor species. No gases other than those shown in Table 9 were detected. The detection limit is about 0.01 volume percent. 
TABLE 7. Experimental Data for Tritıum in Cladding

\begin{tabular}{|c|c|c|c|c|c|c|c|}
\hline Specimen & $\begin{array}{l}\text { Weight } \\
\text { (g) }\end{array}$ & $\begin{array}{c}\text { Date } \\
\text { Outgassed }\end{array}$ & $\begin{array}{c}\text { Outgas } \\
(\mu l-S T P) \\
\end{array}$ & $\begin{array}{c}\text { Outgas in } \\
\text { Aliquot }(\%)\end{array}$ & $\begin{array}{c}H-3 \text { in } \\
\text { Aliquot (dpm) }\end{array}$ & $\begin{array}{c}\text { Tritium } \\
\text { in Cladding } \\
(\mu \mathrm{g} / \mathrm{g}) \\
\end{array}$ & $\begin{array}{c}\text { Outgas } \\
\text { from Claddıng } \\
(\mu l / g) \\
\end{array}$ \\
\hline$Z r-(n o T)$ & 0.237 & $5-11-71$ & 27.2 & 41.6 & $2.2 \times 10^{5}$ & $<1 \times 10^{-4}$ & 115 \\
\hline Std. A & 0.328 & 12 & 45.5 & 38.5 & $4.9 \times 10^{6}$ & $1.8 \times 10^{-3}$ & 138 \\
\hline $\mathrm{CP}-206-\mathrm{N}$ & 0.383 & 14 & 157.6 & 30.1 & $3.2 \times 10^{7}$ & $1.3 \times 10^{-2}$ & 411 \\
\hline CP-206-D & 0.462 & 14 & 222.5 & 34.7 & $3.3 \times 10^{7}$ & $9.4 \times 10^{-3}$ & 482 \\
\hline$C P-206-P$ & 0.490 & 14 & 227.6 & 34.1 & $8.2 \times 10^{7}$ & $2.3 \times 10^{-2}$ & 464 \\
\hline $\mathrm{CP}-206-\mathrm{V}$ & 0.361 & 15 & 120.6 & 33.0 & $2.6 \times 10^{7}$ & $1.0 \times 10^{-2}$ & 334 \\
\hline $\mathrm{CP}-206 \cdot \mathrm{F}$ & 0.387 & 15 & 182.2 & 35.8 & $3.5 \times 10^{7}$ & $1.2 \times 10^{-2}$ & 471 \\
\hline $\mathrm{CP}-206-\mathrm{H}$ & 0.518 & 15 & 200.2 & 35.8 & $2.8 \times 10^{7}$ & $7.1 \times 10^{-3}$ & 387 \\
\hline Std. B & 0.509 & 18 & 115.3 & 33.1 & $1.0 \times 10^{7}$ & $2.9 \times 10^{-3}$ & 227 \\
\hline CP-206-J & 0.534 & 19 & 195.6 & 40.8 & $7.0 \times 10^{7}$ & $1.5 \times 10^{-2}$ & 366 \\
\hline CP-206-C & 0.585 & 19 & 291.6 & 41.2 & $5.0 \times 10^{7}$ & $9.6 \times 10^{-3}$ & 499 \\
\hline CP-206-W & 0.479 & 20 & 178.3 & 39.6 & $3.0 \times 10^{7}$ & $7.5 \times 10^{-3}$ & 373 \\
\hline$C P-206 \cdot R$ & 0.586 & 20 & 240.8 & 40.5 & $7.1 \times 10^{7}$ & $1.4 \times 10^{-2}$ & 411 \\
\hline CP-206-A & 0.582 & 20 & 201.4 & 39.4 & $3.1 \times 10^{7}$ & $6.1 \times 10^{-3}$ & 346 \\
\hline$C P-206-T$ & 0.321 & 20 & 123.8 & 39.1 & $3.3 \times 10^{7}$ & $1.1 \times 10^{-2}$ & 386 \\
\hline CP-206-B & 0.327 & 20 & 553.2 & 33.3 & $4.4 \times 10^{6}$ & $1.9 \times 10^{-3}$ & 1693 \\
\hline $12 \mathrm{FV}-\mathrm{H}$ & 0.330 & 21 & 1172.4 & 25.7 & $2.3 \times 10^{7}$ & $1.2 \times 10^{-2}$ & 3556 \\
\hline $12 F V-R$ & 0.456 & 27 & 1675.8 & 18.8 & $5.5 \times 10^{7}$ & $2.9 \times 10^{-2}$ & 3607 \\
\hline CP-206-X & 0.442 & 21 & 187.3 & 40.0 & $2.3 \times 10^{7}$ & $6.9 \times 10^{-3}$ & 424 \\
\hline $12 \mathrm{FV} \cdot \mathrm{Q}$ & 0.345 & 21 & 1117.7 & 27.4 & $2.5 \times 10^{7}$ & $1.2 \times 10^{-2}$ & 3243 \\
\hline $12 \mathrm{FV}-\mathrm{K}$ & 0.366 & 25 & 827.9 & 35.4 & $1.2 \times 10^{7}$ & $4.3 \times 10^{-3}$ & 2263 \\
\hline $12 \mathrm{FV}-\mathrm{O}$ & 0.345 & 25 & 1183.9 & 29.9 & $2.0 \times 10^{6}$ & $9.0 \times 10^{-4}$ & 3428 \\
\hline $12 \mathrm{FV}-\mathrm{J}$ & 0.326 & 25 & 959.6 & 31.1 & $1.4 \times 10^{7}$ & $6.2 \times 10^{-3}$ & 2948 \\
\hline $12 \mathrm{FV}-\mathrm{S}$ & 0.408 & 25 & 1208.0 & 31.0 & $31 \times 10^{7}$ & $1.1 \times 10^{-2}$ & 2959 \\
\hline Blank & - & 26 & 2.5 & 56.3 & $4.1 \times 10^{4}$ & - & - \\
\hline $12 \mathrm{FV}-\mathrm{L}$ & 0.373 & 26 & 1025.3 & 35.7 & $3.6 \times 10^{7}$ & $1.3 \times 10^{-2}$ & 2746 \\
\hline $12 \mathrm{FV}-\mathrm{E}$ & 0.303 & 26 & 1132.7 & 27.1 & $2.2 \times 10^{7}$ & $1.2 \times 10^{-2}$ & 3742 \\
\hline $12 F V-P$ & 0.356 & 27 & 1295.4 & 27.5 & $1.3 \times 10^{8}$ & $5.9 \times 10^{-2}$ & 3639 \\
\hline $12 \mathrm{FV}-\mathrm{T}$ & 0.761 & 27 & 3259 & 40.4 & $48 \times 10^{6}$ & $7.2 \times 10^{-4}$ & 428 \\
\hline $12 \mathrm{FV}-\mathrm{N}$ & 0.334 & 27 & 1386.0 & 26.2 & $3.5 \times 10^{6}$ & $1.9 \times 10^{-3}$ & 4147 \\
\hline $\mathrm{CP}-206-\mathrm{V}$ & 0.461 & 27 & 206.6 & 39.3 & $57 \times 10^{7}$ & $1.5 \times 10^{-2}$ & 448 \\
\hline $12 \mathrm{FV} \cdot \mathrm{M}$ & 0.507 & 28 & 17243 & 22.6 & $7.2 \times 10^{6}$ & $2.9 \times 10^{-3}$ & 3399 \\
\hline$C P-206-Y$ & 0.740 & 28 & 200.2 & 38.3 & $2.6 \times 10^{7}$ & $4.3 \times 10^{-3}$ & 270 \\
\hline Std. C & 0.861 & $6-2-71$ & 70.4 & 36.5 & $1.1 \times 10^{7}$ & $1.6 \times 10^{-3}$ & 82 \\
\hline
\end{tabular}

The reproducibilities of isotopic abundances reported in Table 10 were calculated at $95 \%$ confidence limits. The accuracy of any abundance figure is within $\pm 2 \%$ of the reported value. For example, the isotopic abundance of $\mathrm{Kr}-83$ in CP-206 lies between 13.27 and $13.81 \%$ with 13.54 being the most probable value; the reproducibility (tolerance) of the value 13.54 is \pm 0.09 at the $95 \%$ confidence limit level.

The ratios of $\mathrm{Xe}$-to- $\mathrm{Xe}+\mathrm{Kr}$ were measured to be 0.884 and 0.905 for $\mathrm{CP}-206$ and PWL-12V, respectively. Those values are accurate to within $\pm 2 \%$ of the true sample values. The accuracy of either ratio relative to the other ratio is within $\pm 0.5 \%$.

The total tritium contents of the gas samples analyzed were $\leqslant 1 \times 10^{-5} \mu \mathrm{g}$ for both rods. The tritium contents on the total gas inside the rods were therefore $\leqslant 1 \times 10^{-3} \mu \mathrm{g}$ and $\leqslant 5 \times 10^{-3} \mu \mathrm{g}$ for Rods CP-206 and $12 \mathrm{FV}$, respectively.

The $\mathrm{Kr}-85$ contents of the two gases were measured on aliquots of 0.175 torr -1 and 0.0975 torr -1 for $\mathrm{CP}-206$ and $12 \mathrm{FV}$ respectively. The atoms of $\mathrm{Kr}-85$ in the aliquots were measured to an accuracy of $\pm 10 \%$ as $3.7 \times 10^{16}$ and $1.6 \times 10^{16}$. Those data, together with the isotopic data in Table 10 and the precision measured $\mathrm{Xe}$-to- $\mathrm{Xe}+\mathrm{Kr}$ ratios correspond to toal $\mathrm{Xe}+\mathrm{Kr}$ releases of $155 \mathrm{ml}$ (STP) and $570 \mathrm{ml}$ (STP) in Rods CP-206 and 12FV, respectively. The accuracy of those total release figures is estimated to be within $\pm 15 \%$ of the true values. 
TABLE 8. Experimental Data for Tritium in Fuel

\begin{tabular}{|c|c|c|c|}
\hline Specimen & $\begin{array}{l}\text { Weight } \\
\text { (g) }\end{array}$ & $\begin{array}{l}\text { Tritium } \\
\text { in Aliquot } \\
\text { (dpm/mi) }\end{array}$ & $\begin{array}{l}\text { Tritrum in Fuel } \\
(\mu g / g)\end{array}$ \\
\hline CP-206-A & 7.85 & $3.15 \times 10^{6}$ & $1.11 \times 10^{-3}$ \\
\hline CP-206-C & 13.08 & $9.86 \times 10^{6}$ & $2.28 \times 10^{-3}$ \\
\hline CP-206-D & 8.10 & $7.34 \times 10^{6}$ & $2.73 \times 10^{-3}$ \\
\hline $\mathrm{CP}-206-\mathrm{F}$ & 8.79 & $7.27 \times 10^{6}$ & $2.57 \times 10^{-3}$ \\
\hline CP-206-H & 11.50 & $1.32 \times 10^{6}$ & $3.48 \times 10^{-3}$ \\
\hline CP-206-J & 9.33 & $1.18 \times 10^{7}$ & $3.62 \times 10^{-3}$ \\
\hline CP-206-N & 10.01 & $1.18 \times 10^{7}$ & $3.54 \times 10^{-3}$ \\
\hline CP-206-P & 9.96 & $1.35 \times 10^{7}$ & $3.96 \times 10^{-3}$ \\
\hline$C P-206-R$ & 7.47 & $7.96 \times 10^{7}$ & $3.14 \times 10^{-3}$ \\
\hline$C P-206-T$ & 8.06 & $6.36 \times 10^{6}$ & $2.31 \times 10^{-3}$ \\
\hline CP-206-V-2 & 7.93 & $7.27 \times 10^{6}$ & $2.46 \times 10^{-3}$ \\
\hline$C P-206-V-3$ & 10.86 & $2.88 \times 10^{6}$ & $6.72 \times 10^{-4}$ \\
\hline Blank-1 & 6.23 & $1.77 \times 10^{4}$ & $7.70 \times 10^{-6}$ \\
\hline Blank-2 & 9.02 & $3.97 \times 10^{4}$ & $1.19 \times 10^{-5}$ \\
\hline Blank-3 & 8.03 & $104 \times 10^{4}$ & $3.51 \times 10^{-6}$ \\
\hline Standard & 8.83 & $352 \times 10^{5}$ & $1.26 \times 10^{-4}$ \\
\hline $12 \mathrm{FV}-\mathrm{B}$ & 1075 & $139 \times 10^{6}$ & $354 \times 10^{-4}$ \\
\hline $12 F V-E$ & 9.79 & $2.20 \times 10^{6}$ & $625 \times 10^{-4}$ \\
\hline $12 \mathrm{FV}-\mathrm{H}$ & 995 & $212 \times 10^{6}$ & $616 \times 10^{-4}$ \\
\hline $12 F V-J$ & 9.50 & $220 \times 10^{6}$ & $6.34 \times 10^{-4}$ \\
\hline $12 \mathrm{FV}-\mathrm{K}$ & 10.17 & $1.97 \times 10^{6}$ & $574 \times 10^{-4}$ \\
\hline $12 \mathrm{FV}-\mathrm{L}$ & 10.22 & $238 \times 10^{6}$ & $625 \times 10^{-4}$ \\
\hline $12 \mathrm{FV}-\mathrm{O}$ & 630 & $821 \times 10^{6}$ & $3.54 \times 10^{-4}$ \\
\hline
\end{tabular}

TABLE 9 Gas Compositions by Mass Spectrometry

\begin{tabular}{llc} 
& \multicolumn{2}{c}{ Volume Percent } \\
\cline { 2 - 3 } & $\underline{\mathrm{CP}-206}$ & $\underline{12 \mathrm{FV}}$ \\
$\mathrm{Xe}$ & 82 & 86 \\
$\mathrm{Kr}$ & 11 & 9 \\
$\mathrm{He}$ & 7 & 3 \\
$\mathrm{~N}_{2}$ & $\mathrm{nd}$ & 3 \\
$\mathrm{CO}_{2}$ & $\mathrm{nd}$ & 003 \\
$\mathrm{H}_{2} \mathrm{O}$ & $<002$ & $<002$
\end{tabular}

TABLE 10 Isotopic Abundances of $\mathrm{Xe}$ and $\mathrm{Kr}$

\begin{tabular}{|c|c|c|}
\hline & CP 206 & $12 \mathrm{FV}$ \\
\hline $\mathrm{Kr}-83$ & $1354 \pm 009$ & $1358 \pm 012$ \\
\hline$K r-84$ & 28 or \pm 016 & $2875 \pm 015$ \\
\hline $\mathrm{Kr}-85$ & $612 \pm 009$ & $486 \pm 007$ \\
\hline $\mathrm{Kr}-86$ & $5229 \pm 020$ & $5281 \pm 016$ \\
\hline$X e-131$ & $1094 \pm 011$ & $1052 \pm 006$ \\
\hline$X e-132$ & $1777 \pm 011$ & $1759 \pm 005$ \\
\hline Xe-134 & $2994 \pm 010$ & $2915 \pm 007$ \\
\hline Xe 136 & $41.35 \pm 016$ & $4275 \pm 010$ \\
\hline
\end{tabular}




\section{DISCUSSION OF RESULTS}

\section{TRITIUM PARTIONING}

The experimental data for tritium in the fuel and cladding (Tables 7 and 8 ) have been plotted in Figures 14 and 15 . The figures show the linear concentration of tritium (in $\mu \mathrm{g}-\mathrm{cm}^{-1}$ ) along the two rods. The figures show a well-defined trend along the length of the fuel in both cases. The distribution of tritium in the cladding of Rod CP-206 is scattered, but reasonably well-behaved, but the tritium distribution in the cladding of 12FV is erratic, especially in the region at the top of the fuel column and extending into the plenum.

Integration of the area under the curves in Figure 14 results in measured total tritium values of $6.0 \mu \mathrm{g}$ in the fuel and $5.3 \mu \mathrm{g}$ in the cladding, for a total of $11.3 \mu \mathrm{g}$. Based on a yield of $1 \times 10^{-4}$ atoms tritium per fission, and a tritium half-life of $12.3 \mathrm{~h}$, the calculated yeild from fission is about $24.2 \mu \mathrm{g}$. The average scatter in the measured tritium of the cladding sections (Figure 14) is about $\pm 30 \%$ (compared to about $\pm 10 \%$ for the fuel) which suggests that the unanalyzed cladding may contain some unaccounted-for tritium.

The cladding tritium values measured for 12FV (Figure 15) are too scattered to perform an accurate integration along the cladding for total tritium. A rough figure of $2 \mu \mathrm{g}$ total tritium in the cladding may be estimated from those data. The fuel tritium data (Figure 15) are very consistent and may be integrated to vield a good figure of $0.48 \mu \mathrm{g}$ tritium in the fuel. Again using a fission yield of $1 \times 10^{-4}$ and a half-life of $12.3 \mathrm{~h}$ for tritium, the calculated yield from $12 \mathrm{FV}$ is found to be $13.1 \mu \mathrm{g}$. The erratic distribution of tritium in the cladding again suggests that the unaccounted-for tritium may be in the cladding.

The average tritium retained in fuel for rods $\mathrm{CP}-206$ and $12 \mathrm{FV}$ are $26 \%$ and $3.7 \%$ respectively. Percent retained tritium from the fuel was calculated based on the measured fuel tritium contents and the calculated tritium production values. This method was chosen because of the unaccounted-for tritium. The tritium values measured for the fuel are believed accurate to within $\pm 10 \%$ and are consistent to within the same tolerance (Figures 14 and 15). The accuracy is based on the $91 \%$ recovered standard sample (Table 8 ) and on a standard which was $98 \%$ recovered in an identical apparatus. ${ }^{15}$

The tritium released from the fuel may be plotted against average linear power rating as shown in Figure 16 . The data of Goode and $\mathrm{Cox}^{4}$ and Melehan 5 are also shown. All rods were Zircaloy- 2 clad $\cup_{2}$, about $1 / 2$ inch diameter. The low power elements received about $32,000 \mathrm{MWd} / \mathrm{Te}$ and $11,400 \mathrm{MWd} / \mathrm{Te}$ average burnup. $A$ clear trend can be seen in Figure 16, that tritium release from the fuel is strongly dependent on linear power rating. The power rating dependence is clearly much stronger than any burnup dependence for these specimens.

\section{LONGITUDINAL TRITIUM MIGRATION}

The longitudinal distribution of tritium in the fuel (Figures 14 and 15) follow the burnup profiles (Figures 4 and 5). For CP-206, the tritium in the cladding also follows the burnup profile, with very little tritium in the fuel-free areas (e.g., the plenum). For 12FV, the longitudinal tritium distribution in the cladding (Figure 15) shows definite signs of thermal migration. 16,17 The difference in longitudinal tritium migration behavior between the two rods can be interpreted based on the experimental conditions. Rod CP-206 was irradiated in a boiling water reactor, where the longitudinal temperature extremes do not exceed about $50^{\circ} \mathrm{C}$. Rod $12 \mathrm{FV}$ was irradiated on the Pressurized Water Loop of GETR; in this case, the plenum was about $150^{\circ} \mathrm{C}$ cooler than the active part of the element. In addition, a sharp temperature gradient existed adjacent to the plenum, where the fuel was operating very hot as can be seen in Figure 3 . Since the thermal flux is dependent ${ }^{17}$ on both temperature and temperature gradient, the observed tritium peak in the plenum and near the hottest fuel of $12 \mathrm{FV}$ is qualitatively in agreement with theory. The very low tritium levels observed in the plenum and end-cap regions of the CP-206 cladding is the result of small temperature gradients in the fuel cladding of a BWR. 


\section{HYDROGEN PICKUP}

The hydrogen levels in the cladding of $12 \mathrm{FV}$ are about an order of magnitude higher than those in CP-206 as shown by the total outgas data (Figure 6). Typically $20-40 \mathrm{ppm} \mathrm{H}_{2}$ were found in $\mathrm{CP}-206$ and $100-200 \mathrm{ppm} \mathrm{H}_{2}$ were found in $12 \mathrm{FV}$, according to the total outgas and gas chromatographic analyses. The excess hydride was present principally at the cladding o.d. in 12FV (Figure 13). These observations can also be explained on the difference between the two irradiation facilities. The PWL was pressurized with hydrogen, while the Big Point Reactor pressure is maintained by the steam from boiling. Increased hydrogen pickup during aqueous corrosion has been shown ${ }^{18}$ to be dependent on hydrogen overpressure. The accumulation of hydrogen at the o.d. is a well-documented ${ }^{16}$ manifestation of hydrogen thermal diffusion. The correlation of total outgas with tritium content on Rod-12FV (Figure 6) indicates that the hydrogen was taken into the cladding during corrosion (dependence on power level) and distributed longitudinally by thermal diffusion (dependence on cladding temperature gradient).

\section{FISSION GAS RELEASE}

The puncture gas analyses (Table 9) show that fission product $\mathrm{Xe}$ and $\mathrm{Kr}$ were the main gases present. Based on an assumed value of 0.33 atoms stable $\mathrm{Xe}+\mathrm{Kr}$ per fission, the total fission gas productions are 0.70 and 0.48 moles for CP-206 and 12FV, respectively. The fission gas recovered from the rods during puncturing was 0.16 and 0.57 moles respectively, or $23 \%$ and $119 \%$ of the assumed productions.

\section{CONCLUSIONS}

The amount of tritium destined for the process water during reprocessing is strongly dependent on the linear power rating of the fuel element. Figure 17 shows the tritium contents of fuel as functions of burnup and maximum linear power rating. The solid lines in Figure 17 are based on the results of this study and earlier studies. The dashed lines are interpolations based on the curve in Figure 16. The solid lines are estimated to be accurate to about $\pm 10 \%$ for fuel cycle times of about 3 years at 20,000 MWd/Te.

Table 11 summarizes the experimental results of this study for total tritium in the fuel rods. Calculated total tritium yields from ternary fission are 24.2 and $13.1 \mu \mathrm{g}$ for Rods CP-206 and 12FV, respectively. The fuel data in Table 11 are accurate to within $\pm 10 \%$. The cladding data are less accurate (especially for $12 \mathrm{FV}$ ) for two reasons: (1) the absolute recovery efficiency for cladding tritium is unknown due to an error (magnitude unknown) in standard preparation; and (2) the sampling procedure for cladding specimens may have resulted in missing some localized areas of high tritium concentration; that such areas exist is indicated by the variability in tritium contents between cladding specimens (Figures 15 and 16). Similar local variability of tritium in cladding was observed by Melehan. ${ }^{5} \mathrm{~A}$ more accurate assessment of total cladding tritium by the technique used will require more cladding specimens and a repeated standard recovery calibration of the analytical chain.

TABLE 11. Experımental Tritium Partıtıoning Summary

\begin{tabular}{|c|c|c|c|c|}
\hline & & & $(\mu \mathrm{g})$ & \\
\hline & Fuel & Claddıng & Gas & $\begin{array}{l}\text { Total } \\
\text { Found }\end{array}$ \\
\hline CP-206 & 6.0 & 53 & $<10^{-3}$ & 11.3 \\
\hline $12 \mathrm{FV}$ & 0.48 & $\sim_{2}$ & $<5 \times 10^{-3}$ & 2.5 \\
\hline
\end{tabular}




\section{ACKNOWLEDGMENTS}

This study was the result of the cooperative efforts of a sophisticated research and development team. Grateful acknowledgment is extended to the following members of that team who performed or directed experimental studies: G. M. Ferguson and R. M. Smith of the Radioactive Handling Operation; J. E. Ward, W. J. Lowe, and W. B. Johnson of the Nuclear Test Reactor Operations; D. F. Rey, F. R. Smıth, E. A. Melaika, J. P. Peterson, E. L. Quevillon, and M. A. Alper of Analytical Chemistry; and M. M. Csicsery and D. Diaz of Ceramic Development.

The authors extend their appreciation to D. Dutına, S. Y. Ogawa, F. H. Megerth, M. F. Lyons, and B. Weidenbaum for their helpful suggestions and technical advice in the selection and characterization of fuel elements; R. L. Boyd and D. Eldred arded ımmeasurably in keeping this task on schedule and within budget. A. 1. Kaznoff provided constructive criticism and review of the manuscript.

Grateful appreciation is extended to L. Rubensteın (AEC-Germantown) and J. P. Halliday (AEC-SAN) for their technical review and guıdance, and to Mr. G. J. Walke of Consumers Power Company whose cooperation made the program possible.

\section{REFERENCES}

1. Ternary Fission, Chairman M. Neve de Mevergnies, in 2nd IAEA Symposium on Physics and Chemistry of Fission, IAEA, Vienna (1969), pp. 83-152

2. F. Ricca, "Thermodynamic Propertıes of Hydrogen and Deuteruum in a Zırconium," J Phys. Chem. 71,3632 (1967).

3. R. G. Barnes, Nuclear Power Reactor Wastes and Our Environment, presented at the Third Annual Natıonal Pollution Control Conference, San Francisco, April 3, 1970

4. J. H. Goode and C. M. Cox. The Distribution of Fission Product Tritium in a Zircaloy-Clad UO 2 Blanket Rod from PWR-1, ORNL TM 2994 (1970).

5. J. B. Melehan, Tritıum Content of a Yankee Core V Zircaloy Clad UO 2 Fuel Rod, E IT 70-208 (1970).

6. F. H. Megerth, Zircaloy Clad $\mathrm{UO}_{2}$ Fuel Rod Evaluation Program, 11th Quarterly Report, GEAP-10217 (August 1970).

7. M. F. Lyons, et al., High Performance $\mathrm{UO}_{2}$ Program, U. S Atomic Energy Commission Contract AT(04 3)-189, Project Agreement 17. Quarterly and Summary Reports

7a. GEAP-5100M, October 1966

7b. GEAP-3771-15, January 1965

7c. GEAP-5100-2, October 1966

8. S. Y. Ogawa, et al., Power Reactor High Performance UO $\mathrm{O}_{2}$ Program, U S Atomic Energy Commission Contract AT(04-3)-189. Project Agreement 50. Quarterly and Summary Reports

8a. GEAP-10032, June 1969

8b. GEAP.5751, October 1968

8c. GEAP-10042, June 1969

9. P. W. Mathay, Post-Irradiatıon Examınation of Mitsubıshı Fuel, GEIC-1046 (September 1966).

10. B. F. Rider, C. P. Ruiz, J. P. Peterson, Jr., and F R Smith, Determination of Nd 148 in Irradiated Uranium and Plutonium as a Measure of Burnup, GEAP-5354 (October 1967) Also see ASTM Method E-321. The computer code used is in GEAP-5355. 
11. R. E. Smith and D. L. Zimmerman, Post-Irradiation Examination of PNC-1RT(A) and -1RT(C) Mixed Oxide Fuel, NEDC-12107 (September 1970).

12. M. M. Csicsery and L. N. Grossman, Tritium to Water Conversion and Mass Spectrometric Analyses of Gases in Irradiated Cladding, NEDM-12129 (1970).

13. F. H. Megerth, Zircaloy-Clad $\mathrm{UO}_{2}$ Fuel Rod Evaluation Program, Quarterly Progress Report No. 11, May-July 1970, GEAP-10217 (August 1970).

14. G. C. Martin, Radiation Specification and Procedure Manual, APIO-1104 (September 1968) (Revision in progress).

15. Letter of June 10, 1971, D. Dutina (GE-NL) to G. Wozadlo (GE-BRDO).

16. J. M. Markowitz, "The Thermal Diffusion of Hydrogen In Alpha-Delta Zircaloy-2," Trans. Met. Soc. A/ME, 221, 819-824 (1961).

17. P. Shewmon, "The Redistribution of a Second Phase During Annealing in a Temperature Gradient," Trans. Met. Soc. AIME, 212,642 (1958).

18. E. Hillner, Hydrogen Absorption in Zircaloy During Aqueous Corrosion, Effect of Environment, WAPD-TM-411 (November 1964). 


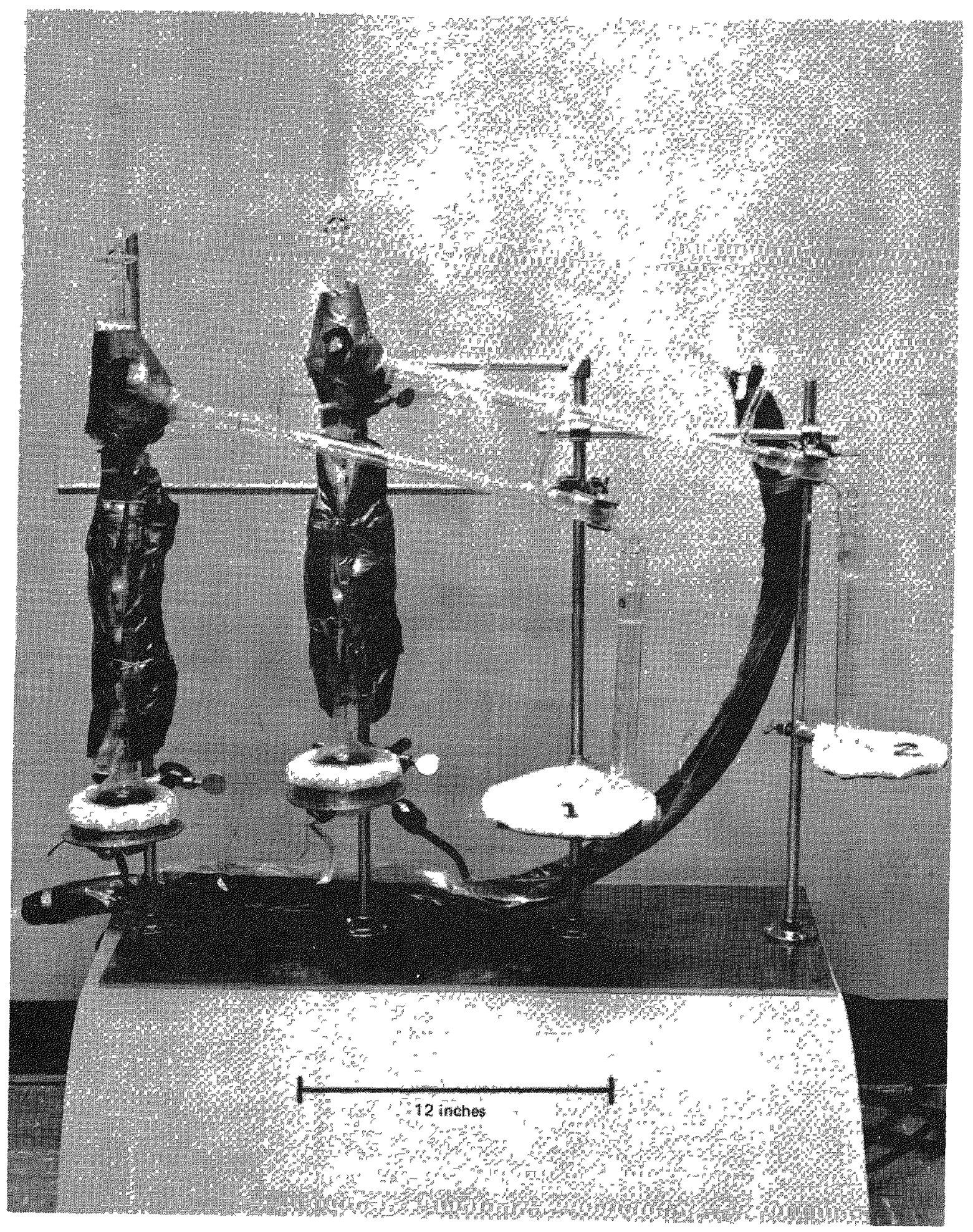

FIGURE 1. TWIN DISTILLATION APPARATI FOR RECOVERY OF TRITIUM FROM FUEL 



FIGURE 2a. NEUTRON RADIOGRAPHY OF ROD CP206 

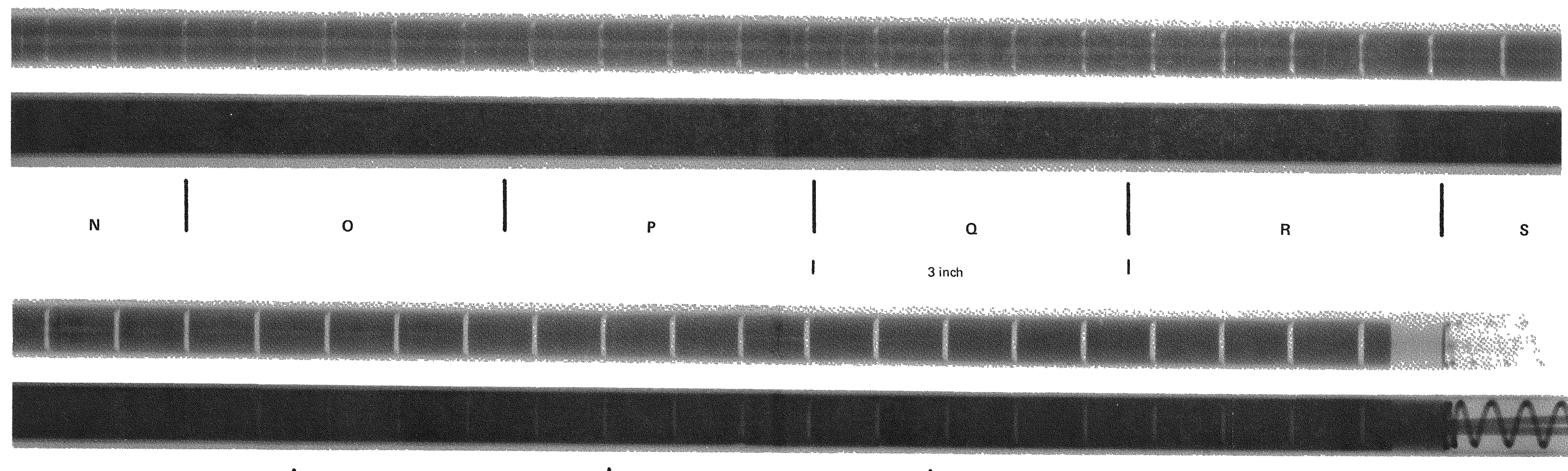

s
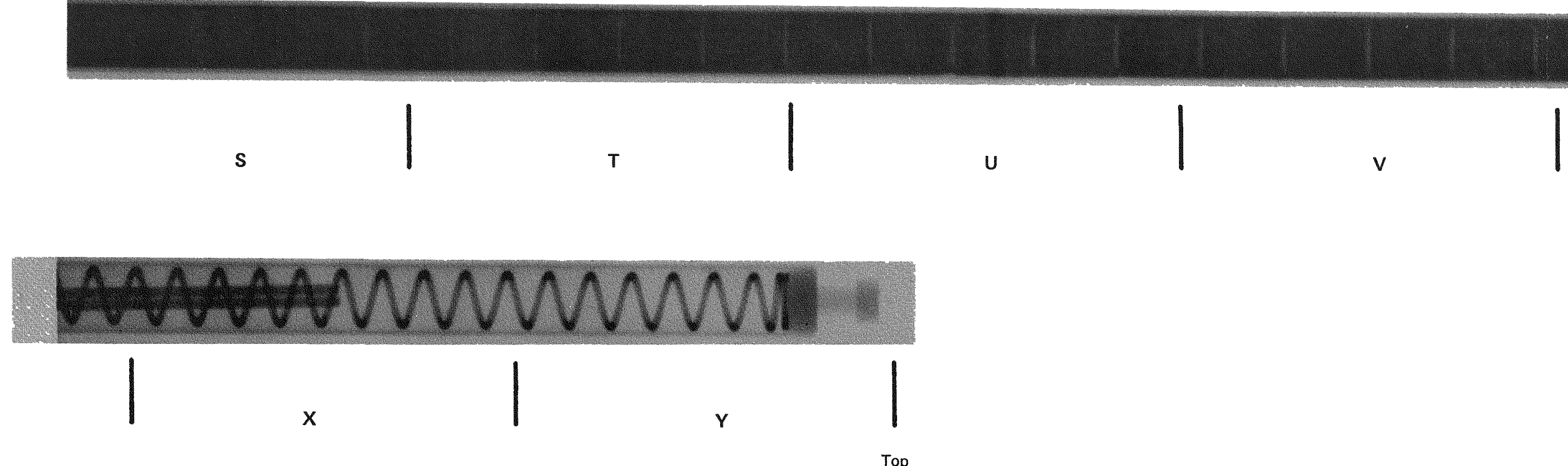

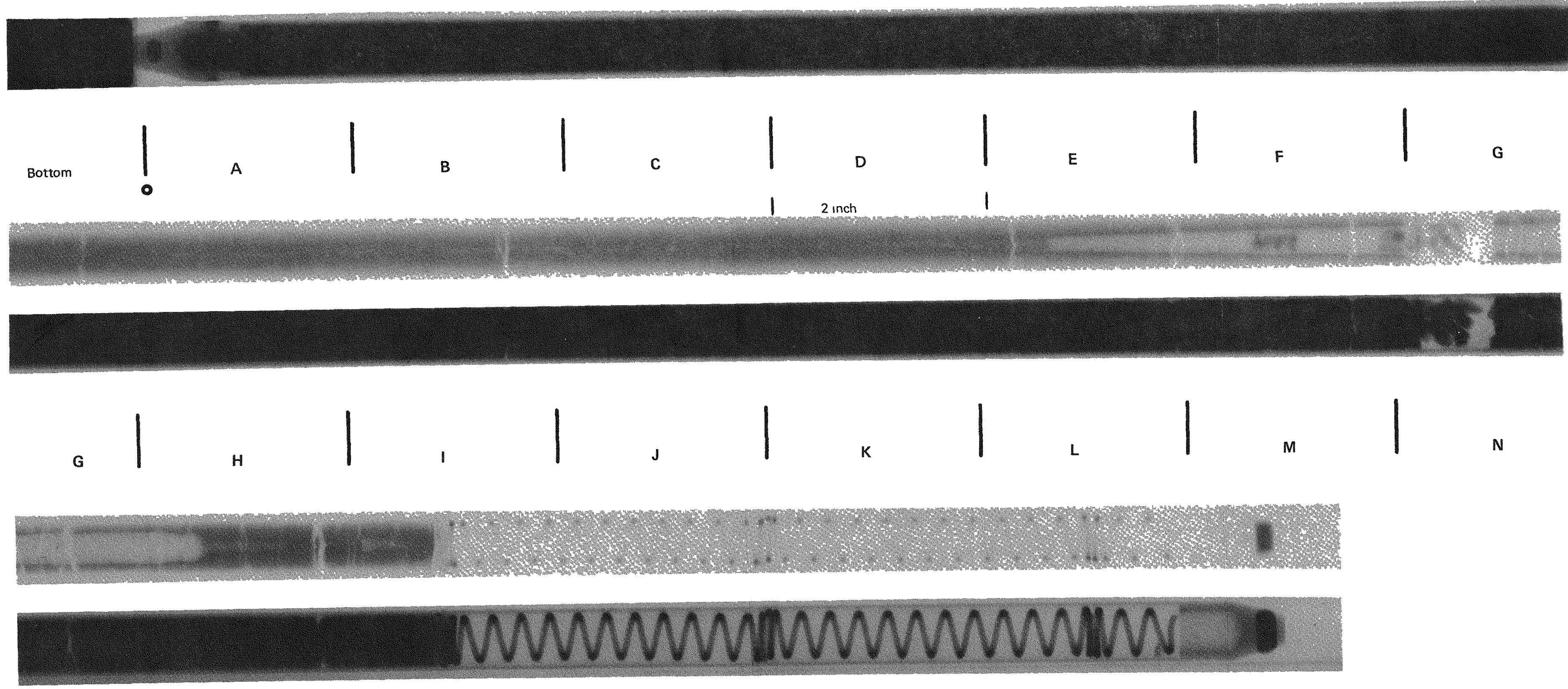
.1
o
o
R
s
T Top 

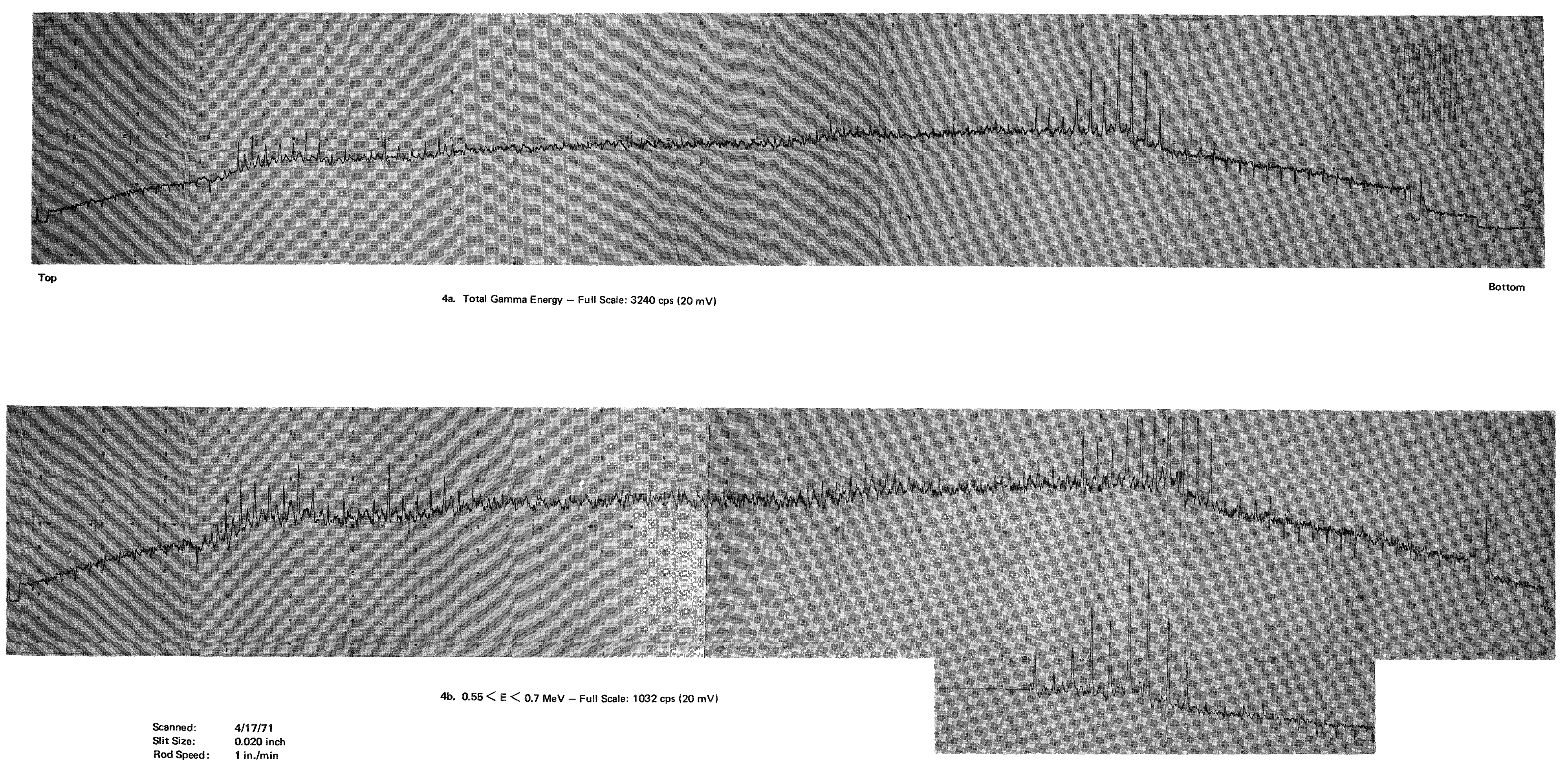


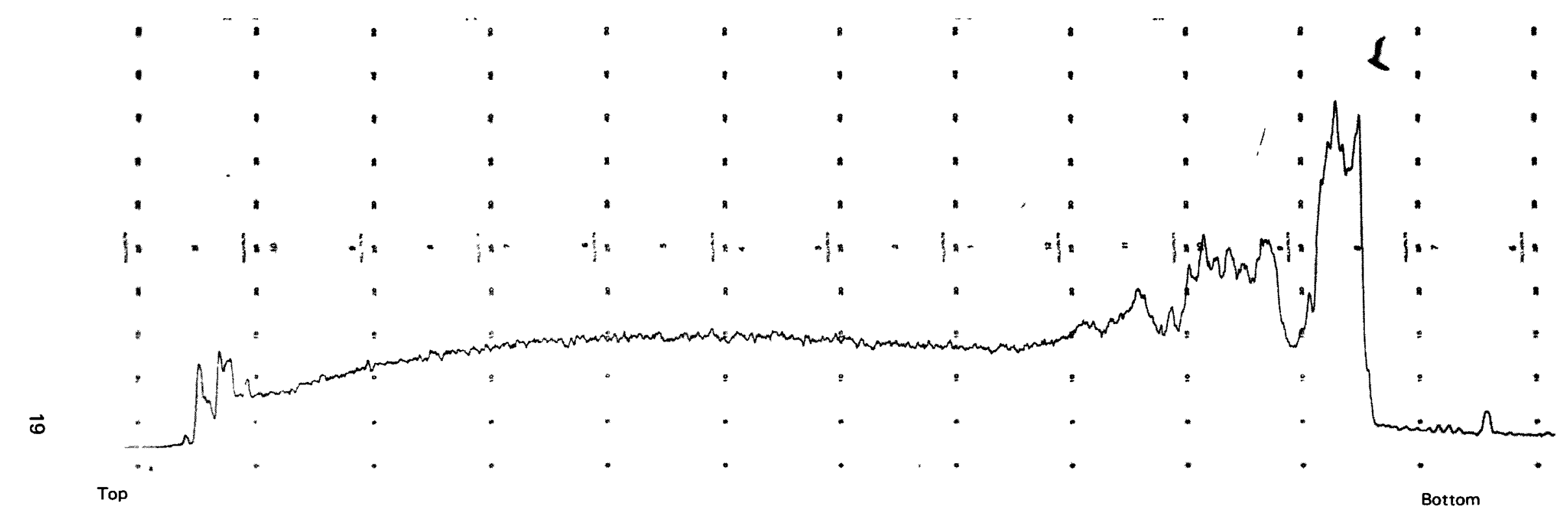

$\begin{array}{ll}\text { Date Scanned: } & 4 / 26 / 71 \\ \text { Slit Size: } & 0.062 \text { inch } \\ \text { Rod Speed: } & 1 \text { in./min } \\ \text { Gamma Energies: } & 0.55 \text { to } 0.7 \mathrm{MeV} \\ \text { Full Scale: } & 5800 \mathrm{cpm}(20 \mathrm{nV})\end{array}$





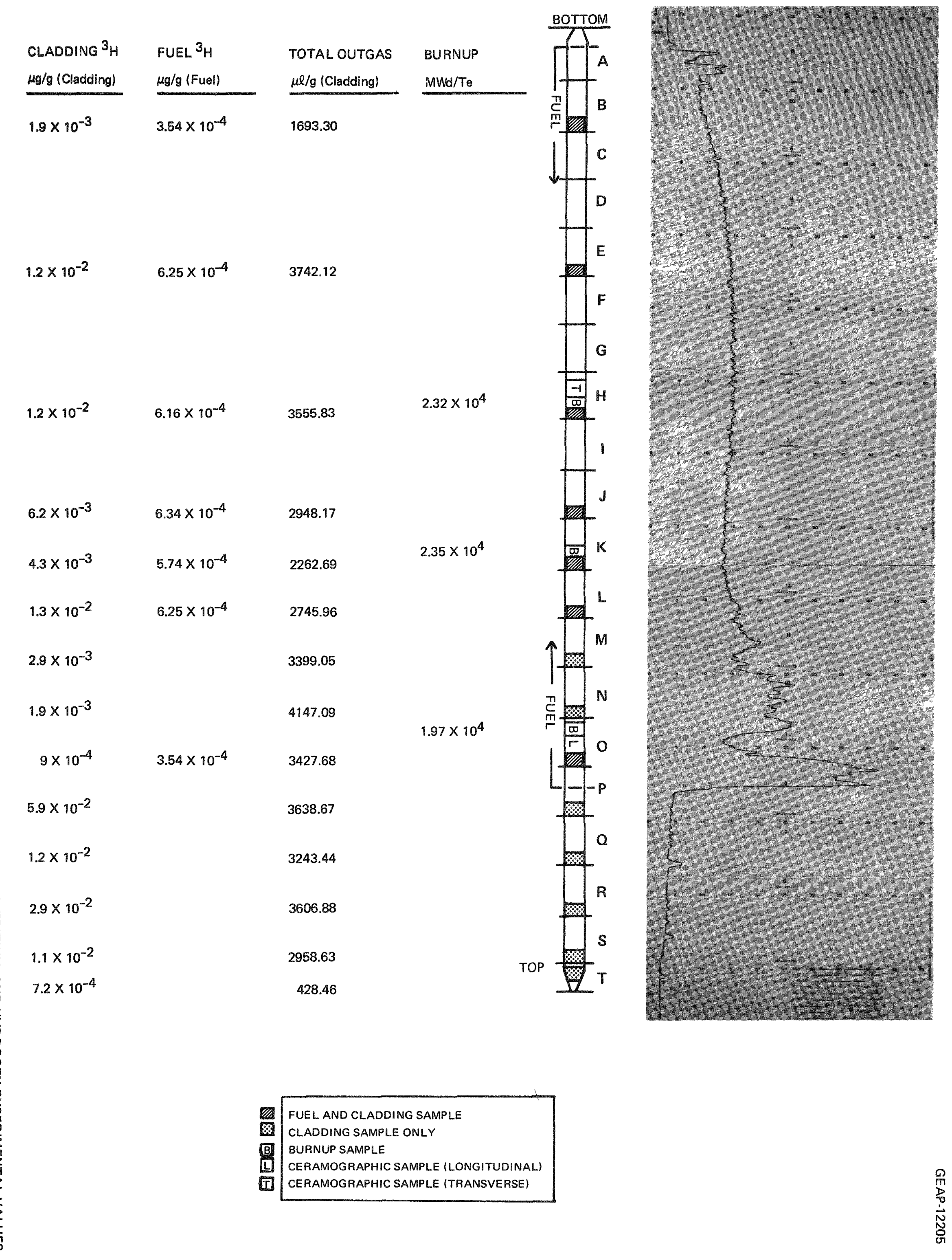




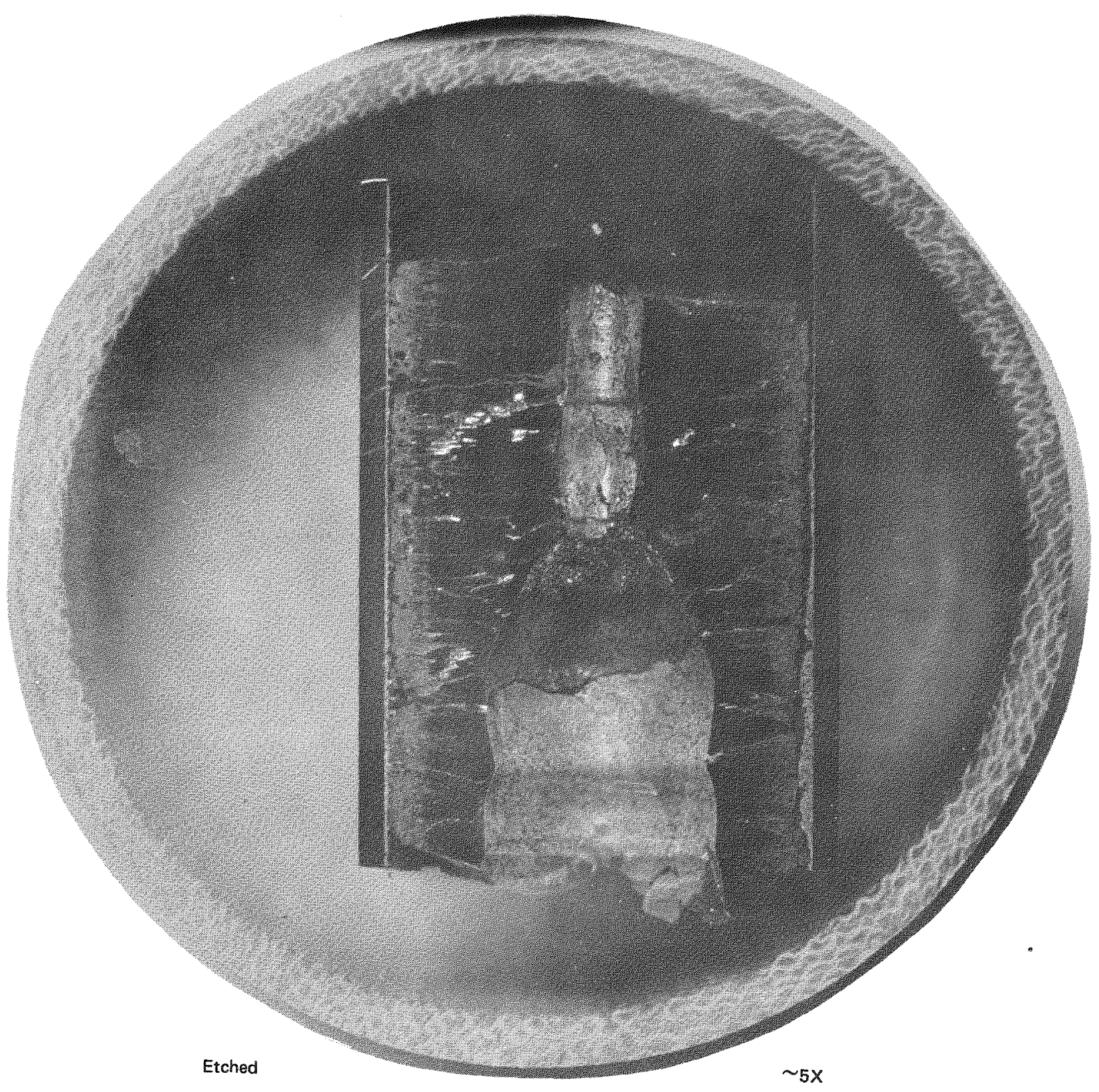

FIGURE 8. LONGITUDINAL MACROSECTION FROM ROD 12FV, TOP OF FREEZING VOID ISEGMENT O) 




FIGURE 9. LONGITUDINAL MACROSECTION FROM ROD CP206, SEGMENT R 


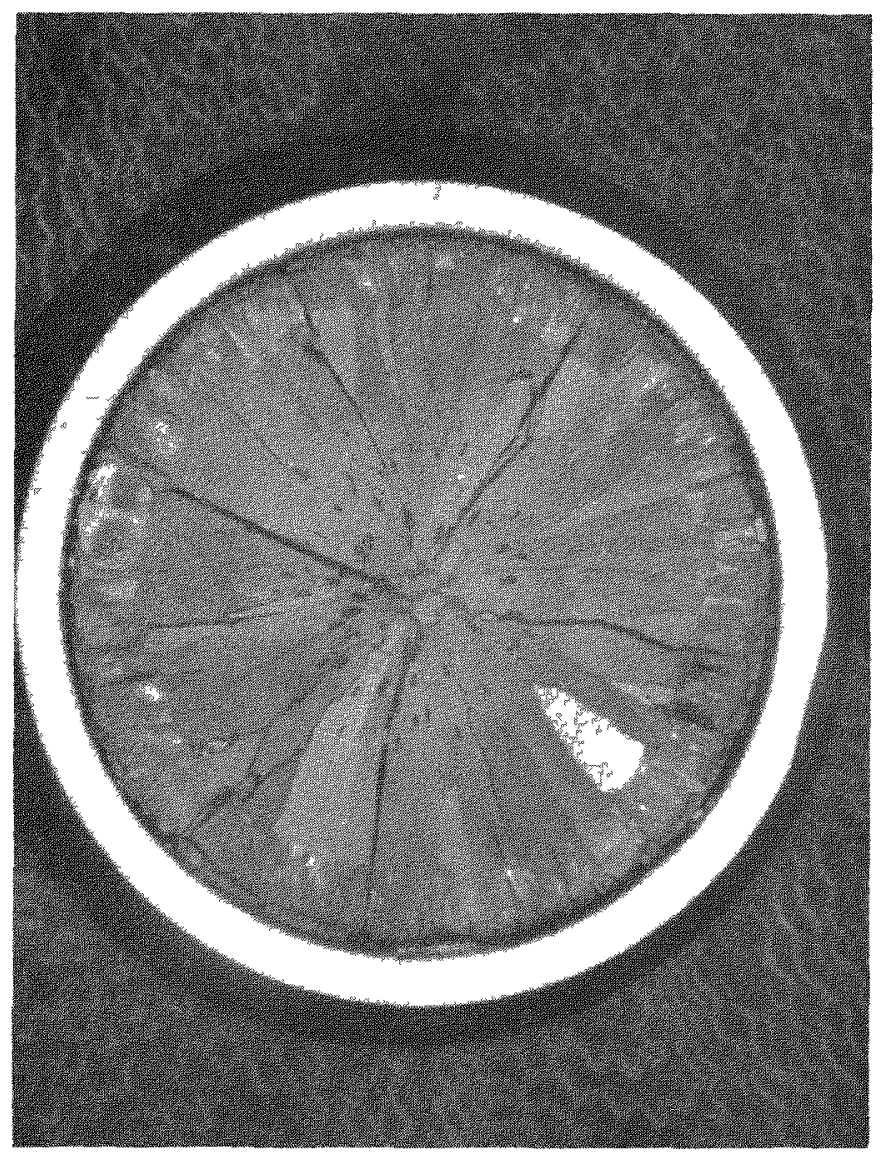

As Ground $\sim 5 x$

Rod $12 \mathrm{FV}$, Segment $H$

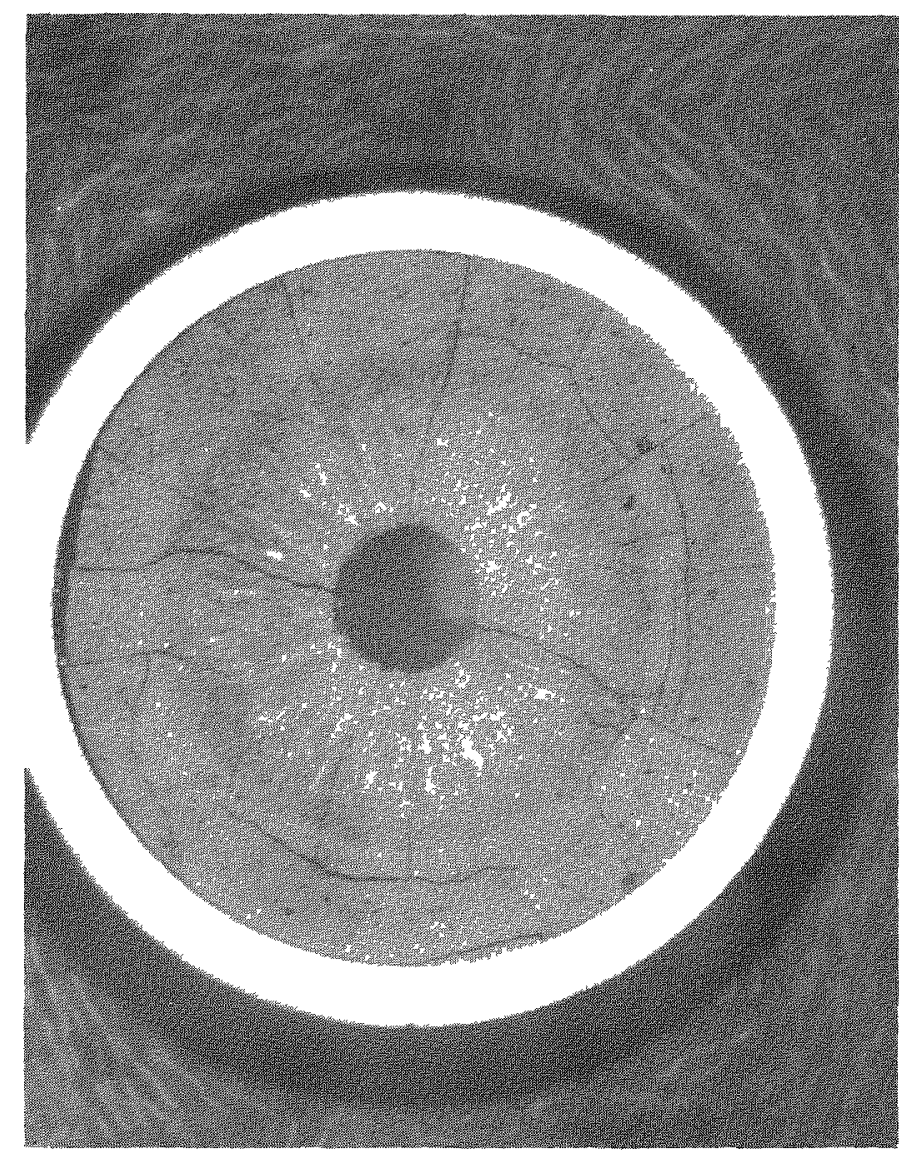

As Ground

$\sim 5 x$

Rod CP206, Segment $P$

FIGURE 10. TRANSVERSE SECTION MACROGRAPHS 

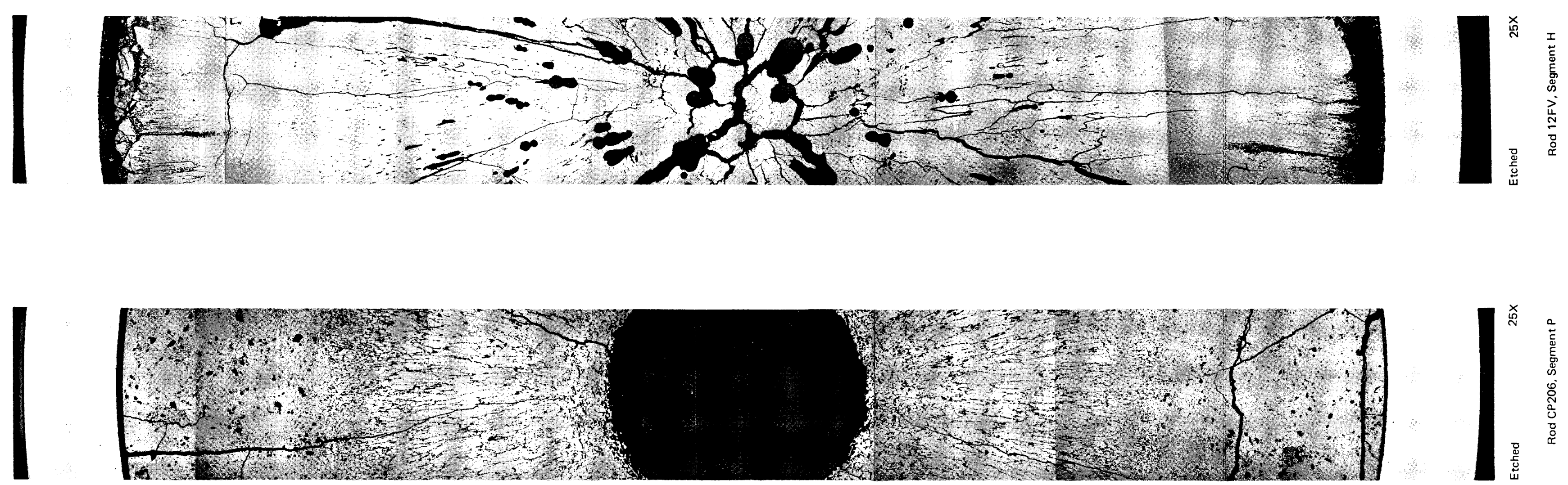


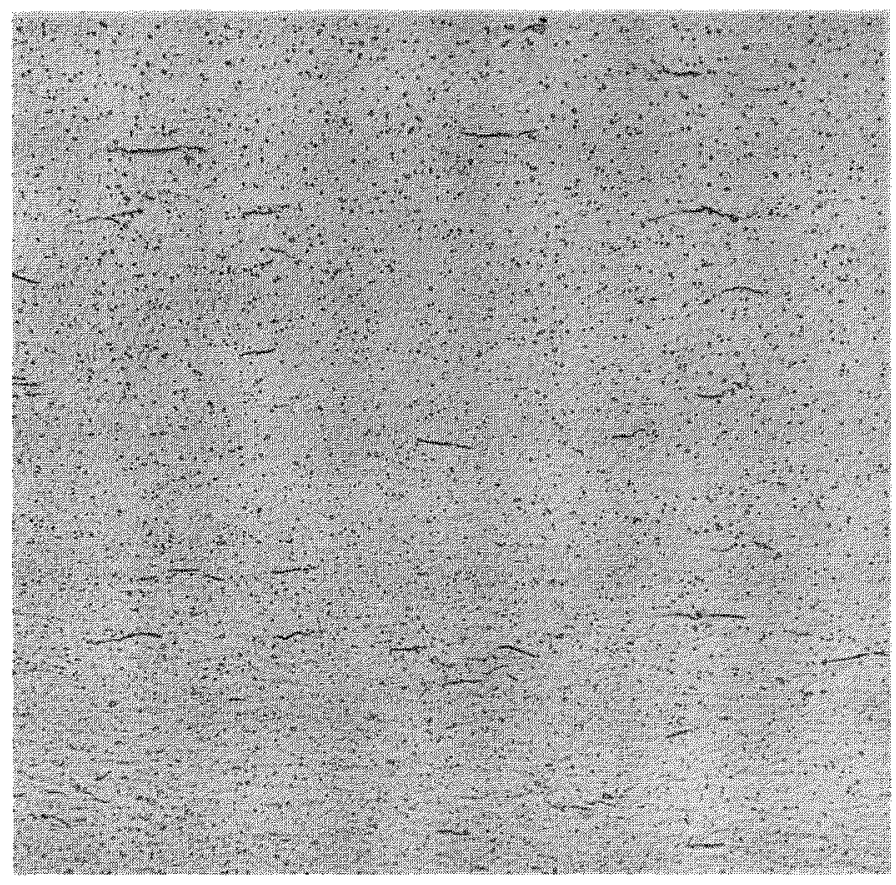

Etched

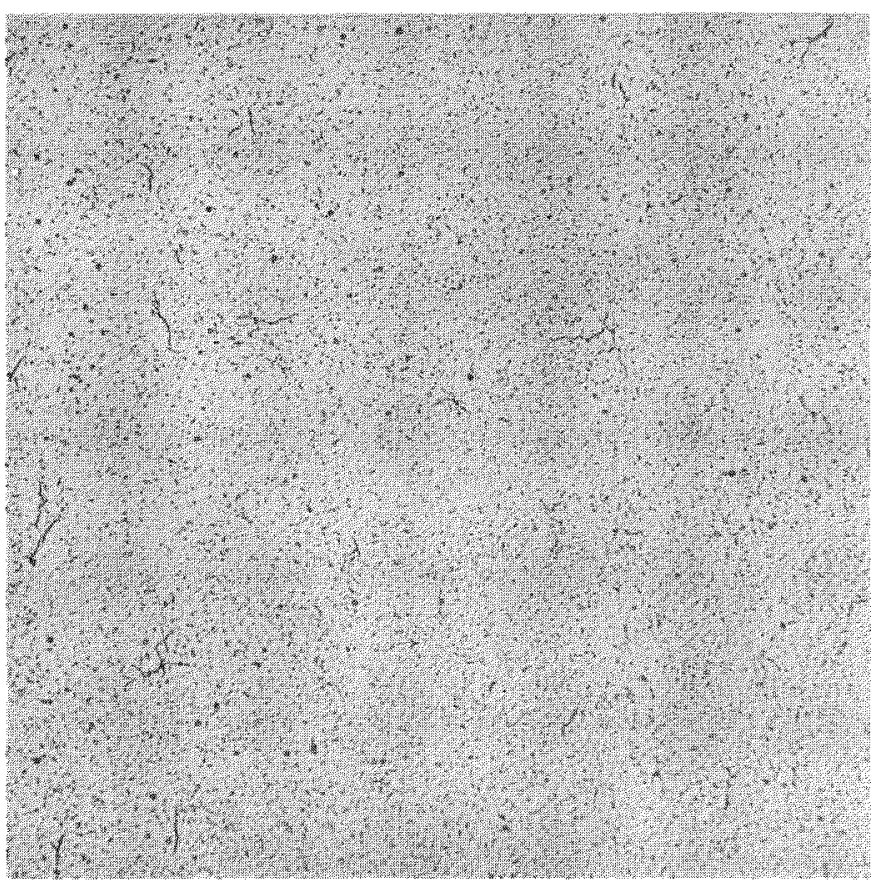

Etched
Rod CP206 Transverse Section

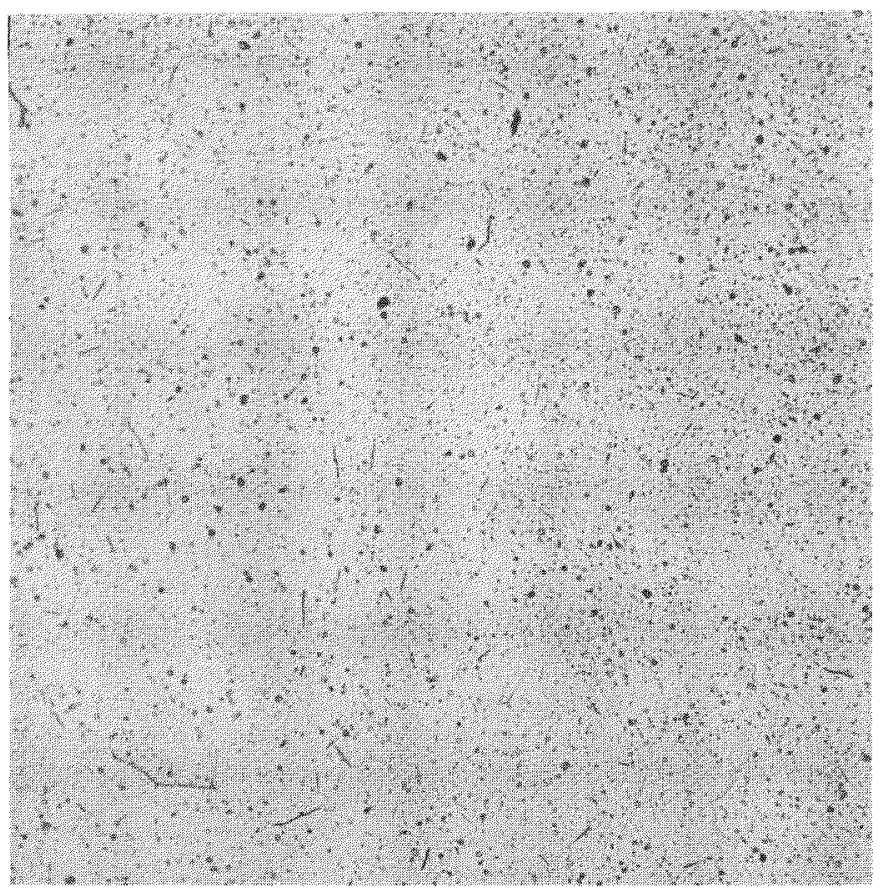

Etched

$250 x$

Rod 12FV Longitudinal Section

$250 x$

Rod 12FV Transverse Section

FIGURE 12. TYPICAL CLADDING MICROSTRUCTURES SHOWING HYDRIDES 


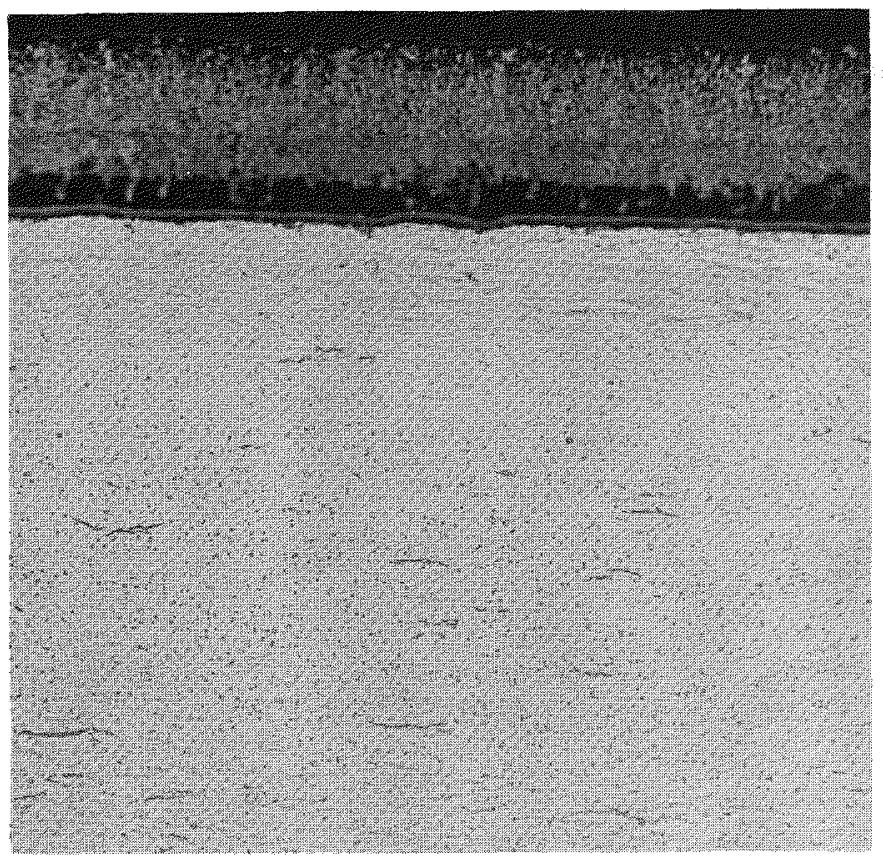

Etched

Rod CP206 Longitudinal Section

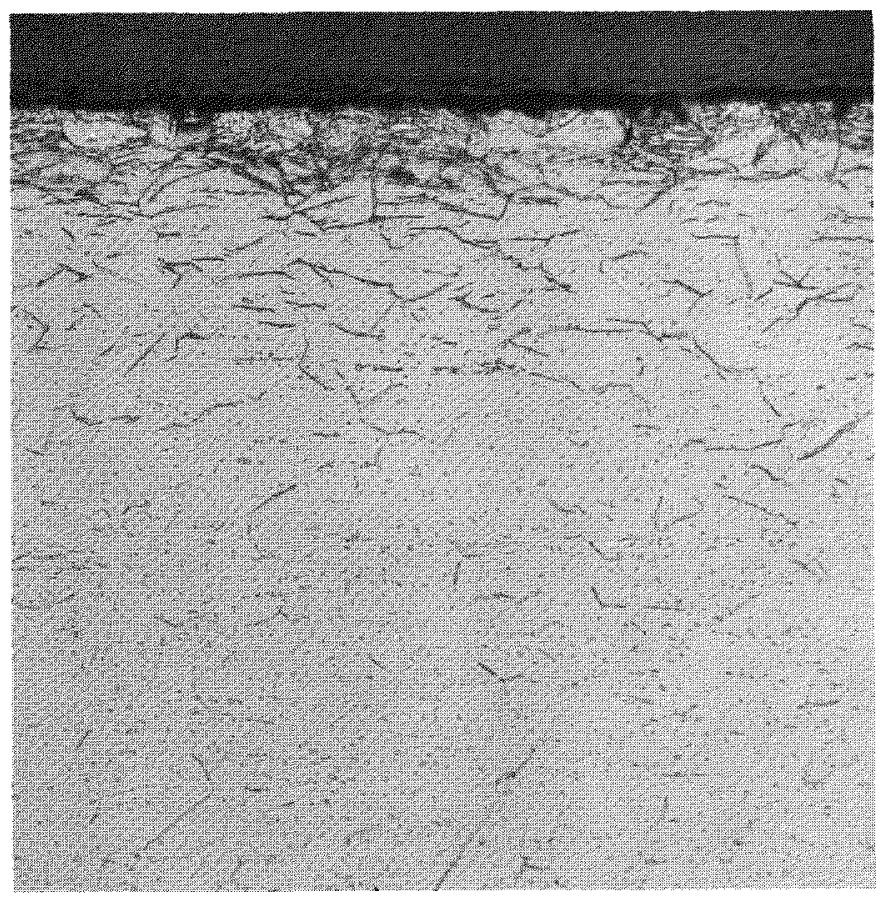

Etched

Rod 12FV Longitudinal Section



Rod CP206 Transverse Section

$250 x$

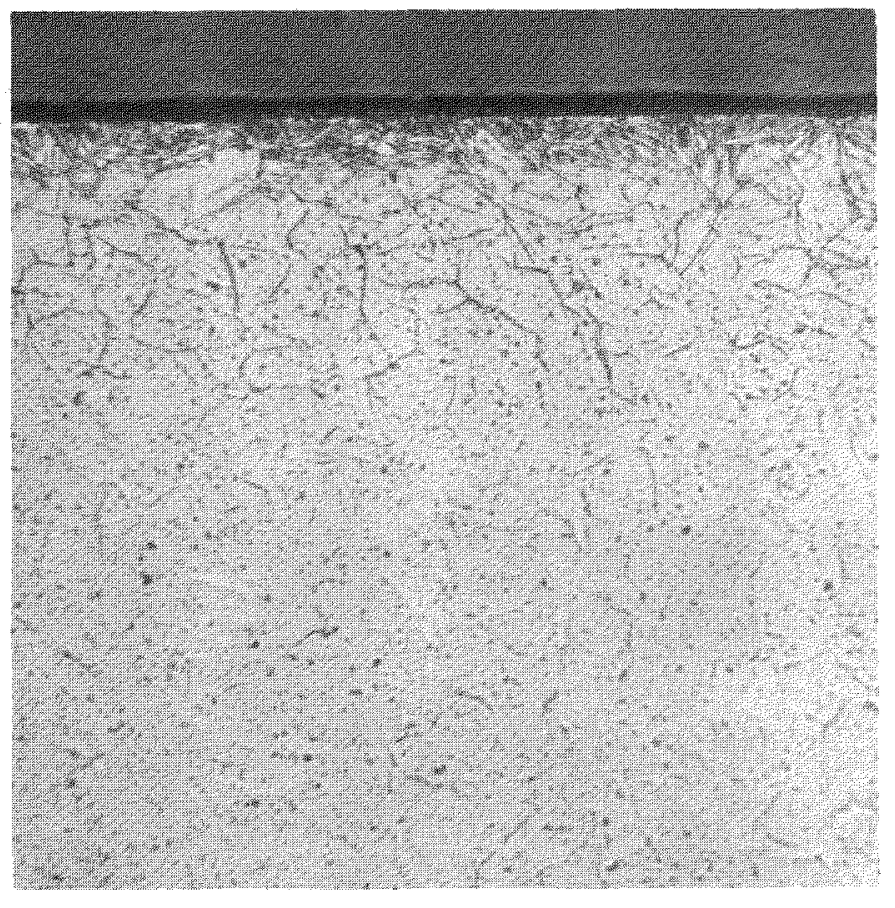

Rod 12FV Transverse Section

$250 x$

FIGURE 13. MICROSTRUCTURES SHOWING HYDRIDE AT CLADDING OUTSIDE DIAMETER AND CRUD LAYERS 


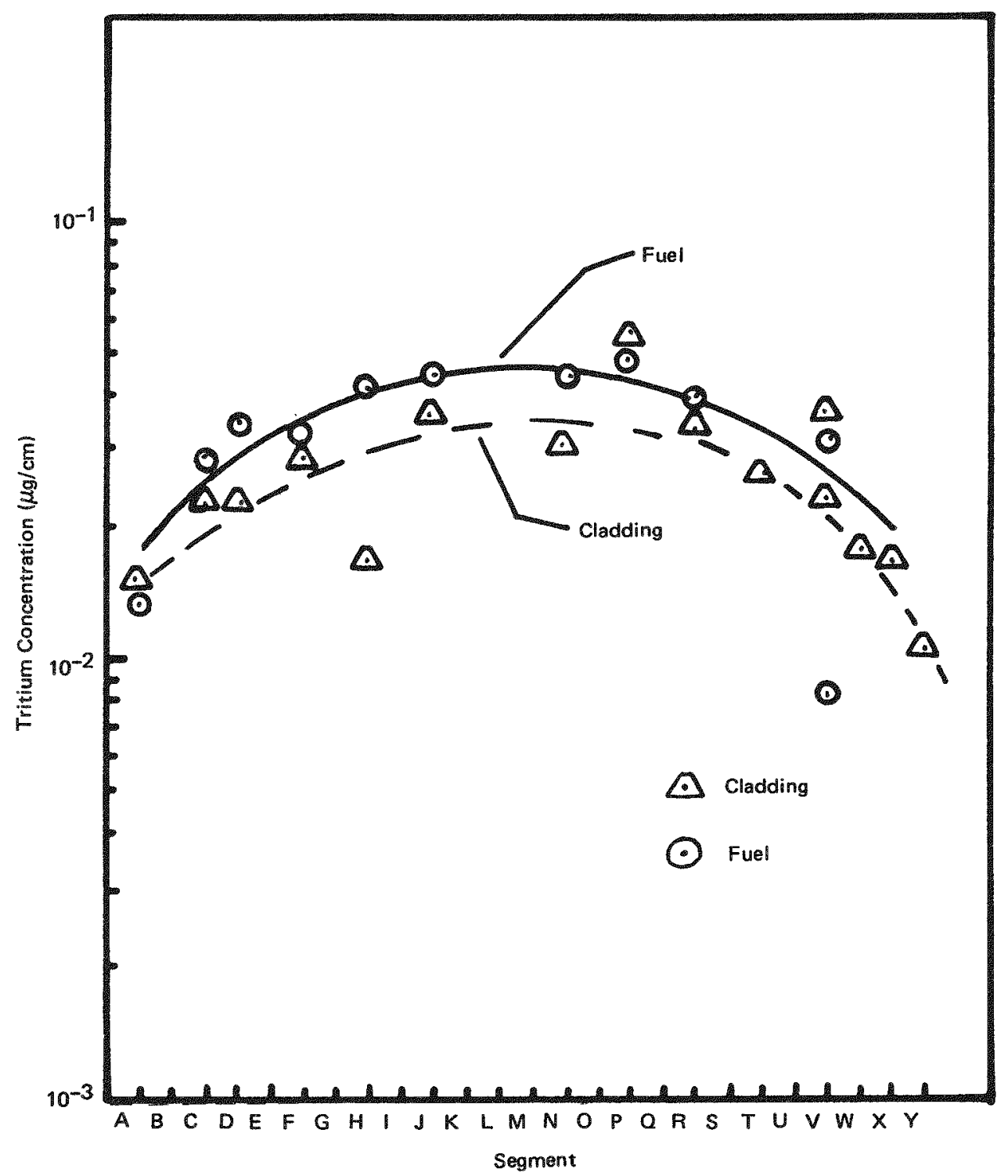

FIGURE 14. TRITIUM DISTRIBUTION IN ROD CP206 


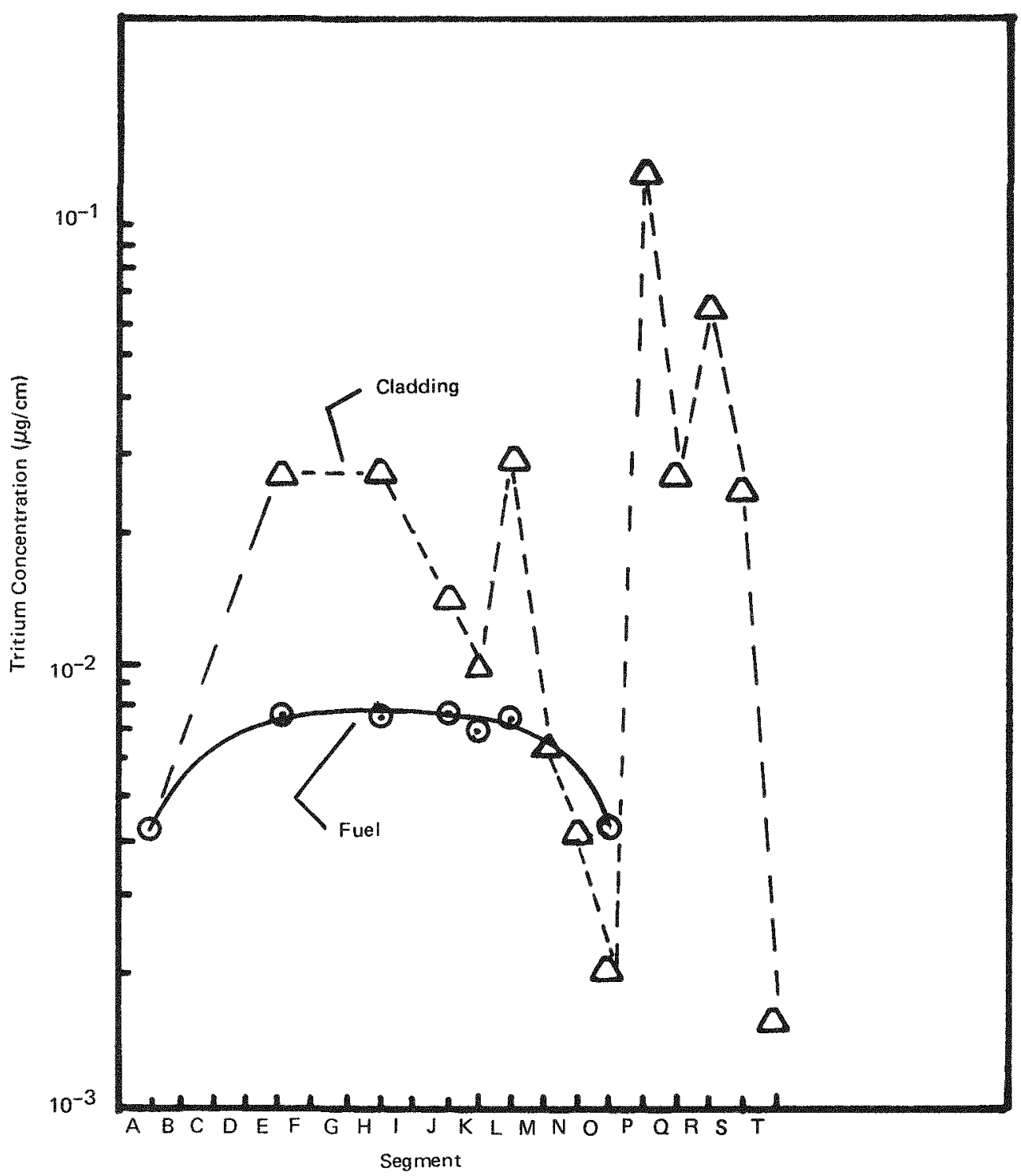

FIGURE 15. TRITIUM DISTRIBUTION IN ROD 12FV 


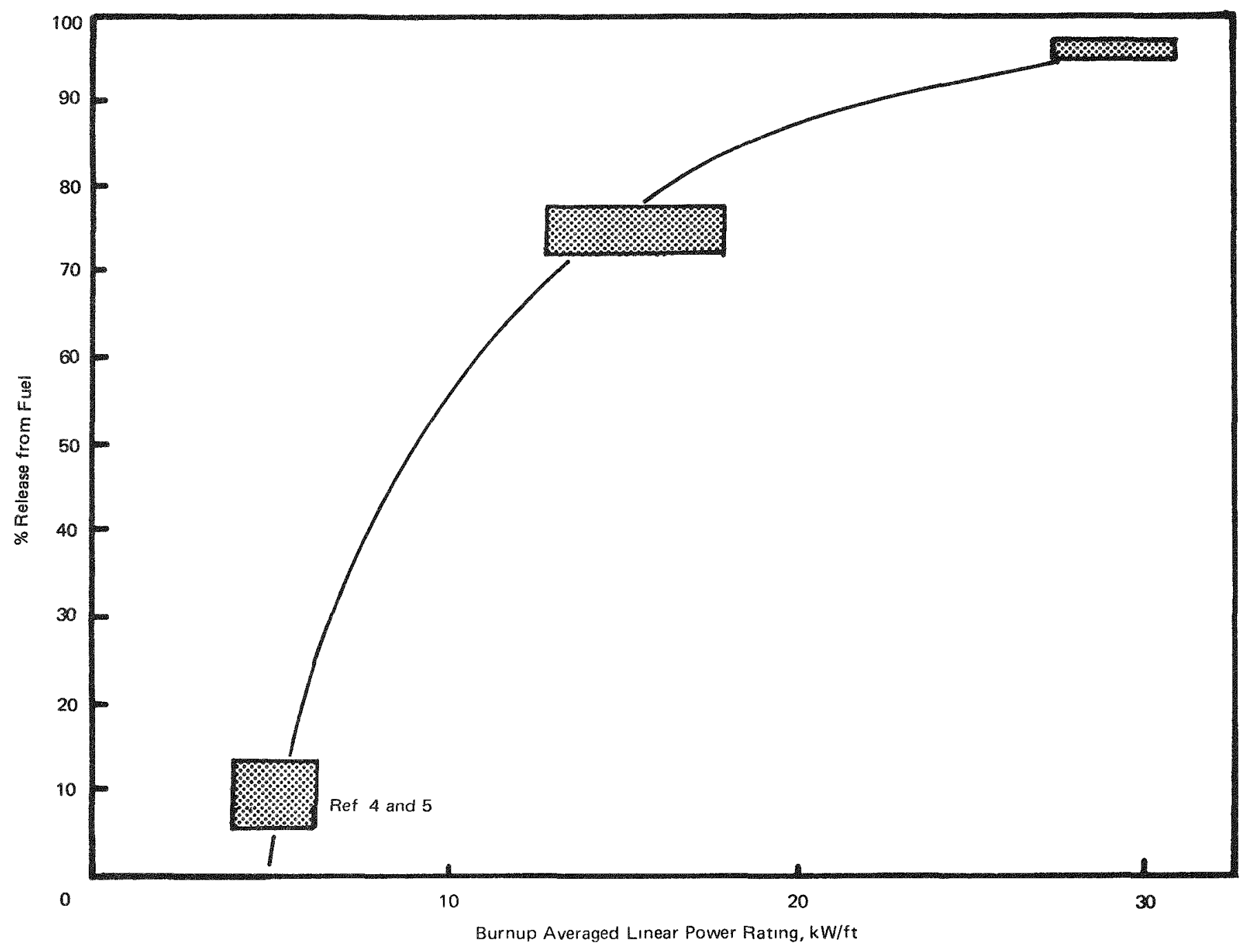

FIGURE 16 TRITIUM RELEASE VS LINEAR POWER 




FIGURE 17. TRITIUM IN FUEL VS. BURNUP 


\section{APPENDIX A \\ INSTRUCTIONS FOR SECTIONING OF FUEL ELEMENTS}

\section{GENERAL}

1. Dimensıons referred to are taken from the neutron radıographs.

2 Tritıum samples are to be $3 / 8$ inch long sections.

3 Burnup samples are to be $3 / 8$ inch long sections of fuel

4. Ceramographıc samples are to be $3 / 4$ ınch long sections of fuel and claddıng. (One longıtudınal and one transverse from each rod as noted.)

$5 \quad$ Tritıum samples are not to include a pellet interface.

6. Tritıum samples are to be taken from the top end of segments if possible. (Note any necessary change in sample locations )

7. Tritıum samples include fuel and claddıng in fuel column area Cladding only in plenum area. (Unless otherwise noted.)

8 Burnup samples are to be taken next to tritıum samples

\section{ROD CP206 (BRP)}

1 Define zero inches as flat end of bottom end plug First pellet is approxımately 1.19 inches up from zero. Fuel column length is approximately $663 / 8$ inches

2. Startıng from zero reference, cut rod into 3 inch segments Identify each segment with a letter, startıng with $A$ at the bottom and ending with $Y$ at the top

3. Identıfy orientation of each segment

4 Usıng ground rules described above, remove samples from segments according to Table A-1 


\section{GEAP-12205}

TABLE A-1. Sample Locations for Rod CP206

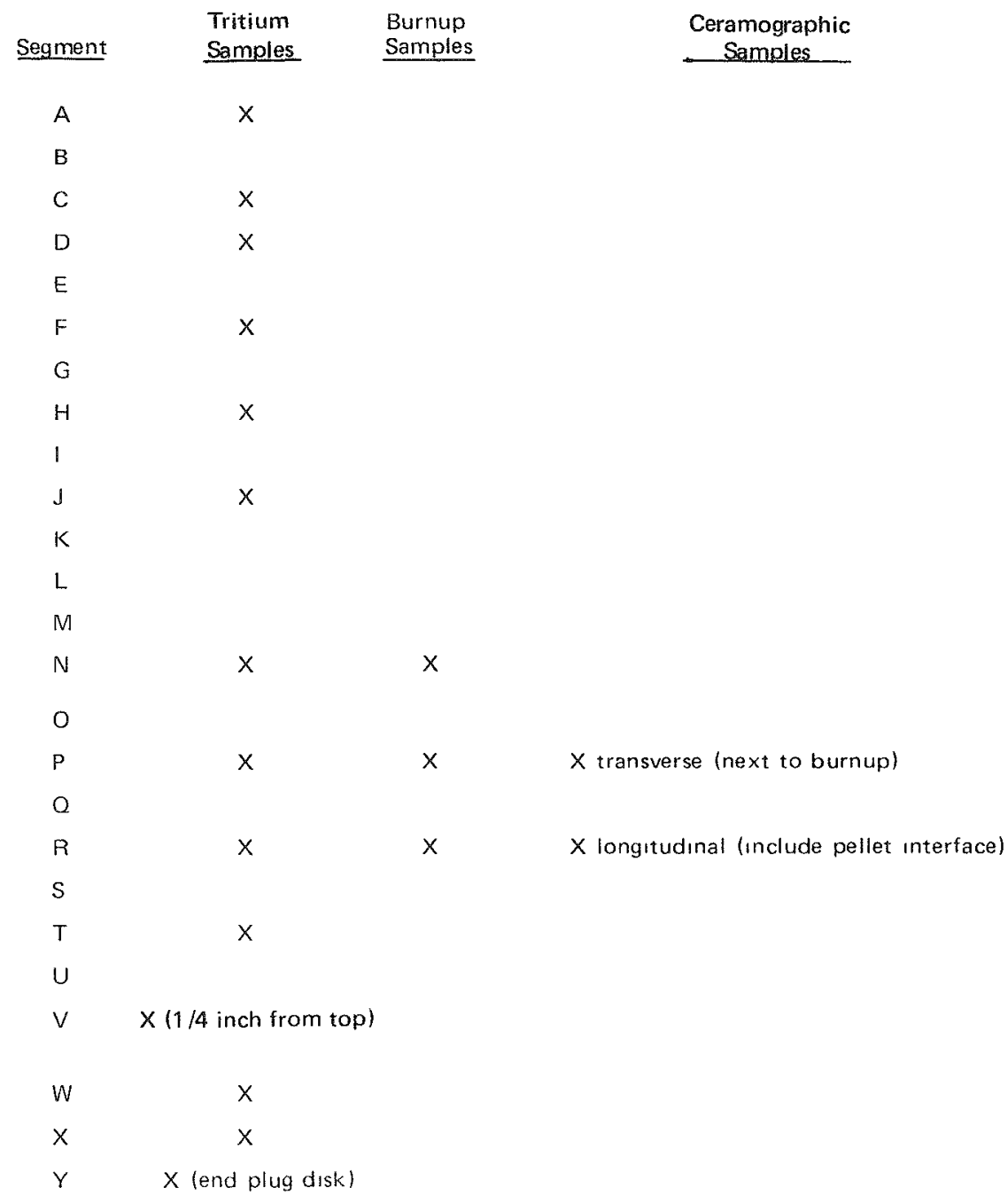

MAINTAIN IDENTIFICATION OF ALL SAMPLES 


\section{ROD 12FV (PWL)}

1. Define zero inches as flat end of bottom end plug. First pellet is approximately 1 inch up from zero. Fuel column length is approximately $30-5 / 8$ inches. (Length includes $5 / 8$ inch of powder in bottom end plug.)

2. Starting from zero reference, cut rod into 1 -inch segments. Identify each segment with a letter, starting with $A$ at the bottom and ending with $T$ at the top.

3. Identify orientation of each segment.

4. Using ground rules described above, remove samples from the segments according to Table A-2.

\section{NOTE}

Segments $M$ and $N$ should be originally cut as one 4-inch segment. Carefully split the 4-inch segment longitudinally trying to maintain fuel in position. Call for inspection of 4-inch longitudinal sections at this point.

MAINTAIN IDENTIFICATION OF ALL SAMPLES

TABLE A.2. Specimen Locations for Rod $12 F V$

\begin{tabular}{|c|c|c|c|}
\hline Segment & $\begin{array}{l}\text { Tritium } \\
\text { Samples } \\
\end{array}$ & $\begin{array}{l}\text { Burnup } \\
\text { Samples }\end{array}$ & $\begin{array}{c}\text { Ceramographic } \\
\text { Samples } \\
\end{array}$ \\
\hline \multicolumn{4}{|l|}{ A } \\
\hline B & $x$ & & \\
\hline \multicolumn{4}{|l|}{$\mathrm{C}$} \\
\hline \multicolumn{4}{|l|}{$\mathrm{D}$} \\
\hline$E$ & $x$ & & \\
\hline \multicolumn{4}{|l|}{$F$} \\
\hline \multicolumn{4}{|l|}{ G } \\
\hline $\mathrm{H}$ & $x$ & $x$ & $X$ transverse (next to burnup) \\
\hline \multicolumn{4}{|l|}{1} \\
\hline s & $x$ & & \\
\hline K & $x$ & $x$ & \\
\hline$L$ & $x$ & & \\
\hline M & $X($ clad only $)$ & & \\
\hline$N$ & $X($ clad only $)$ & & \\
\hline 0 & $x$ & $X($ in molten zone $)$ & $\begin{array}{l}X \text { longitudinal (top of molten zone. } \\
\text { Center of } 0 \text { ) }\end{array}$ \\
\hline$P$ & $X($ clad only $)$ & & \\
\hline Q & $x$ & & \\
\hline $\mathrm{R}$ & $x$ & & \\
\hline s & $x$ & & \\
\hline$T$ & $X$ (end plug dis & & \\
\hline
\end{tabular}

MAINTAIN IOENTITY OF ALL SAMPLES 


\section{APPENDIX B}

\section{INSTRUCTIONS FOR RECOVERY OF TRITIUM FROM FUEL}

A summary of events is as follows: A fuel sample of known weight is placed in a receiver and dissolved in acid with low heat under reflux. When the reaction is complete and heat input is increased to force a portion of the dissolver solution up the reflux column as vapor and out the condenser as liquid. This liquid is essentially water. The water is then sampled and transferred to the radiochemistry laboratory for tritium analysis; the remaining solutions are stored. A detailed work sheet guide will be followed with entries of weights, volumes, and other pertinent data carefully recorded. Constant attention will be required to maintain sample identity.

1. Locate sample (note fuel and cladding are in same vial), remove cladding, weigh vial. Place fuel in dissolver pot and reweigh vial. Return cladding to vial. Maintain identity.

2. Load receiver with 7 to $9 \mathrm{cc}$ of distilled water. Note actual volume and place on equipment; check for completeness of setup (top stopcock closed).

3. Measure out approximately $50 \mathrm{cc}$ of dissolver solution $8 M \mathrm{HNO}_{3}$ (note actual volume accurately) and add to pot.

4. Dissolve fuel with low heat Variac at 40 - reduce if rapid reaction is indicated. Check security by observing bubbles in receiver. (No heat was required except on the unirradiated specimen.)

5. As fuel dissolution nears completion, start helium flow to pre-cool the condenser and line, set to $90 \mathrm{CFH}$.

6. After dissolution, apply insulation blanket to the reflux column and raise the heat. Set Variac to 100 and distill over a volume of $25 \mathrm{ml}$. Watch condensation line carefully add or subtract heat to prevent vapor passage.

7. Turn off heat and open top stopcock to prevent back up of distillate.

8. Stop helium flow when temperature is down to near ambient cell temperature.

9. Remove receiver and sample about $5 \mathrm{ml}$ in a polysealed glass bottle. Measure aliquot accurately. Transfer to NL - Analytical Chemistry.

10. Store distillate in polyethylene bottle and store dissolver solution in a second bottle.

11. Rinse both the pot and receiver with distilled water.

12. Fill pot with approximately $50 \mathrm{ml}$ of distilled water and run heat at $115 \mathrm{~V}$ to drive over about 10 to $15 \mathrm{ml}$. 
TRITIUM DISTILLATION WORK SHEET

Sample Identity Vial

Equipment No.

Run No.

Date

Sample Weight:

Gross

grams

Tare grams

Net grams

Volume of $\mathrm{H}_{2} \mathrm{O}$ in receiver $\mathrm{ml}$

Volume of $8 M \mathrm{HNO}_{3}+$ dissolver solution solution $\mathrm{ml}$

Volume of distillate:

Receiver total $\mathrm{ml}$

Less initial $\mathrm{H}_{2} \mathrm{O}$ $\mathrm{ml}$

Distillate volume $\mathrm{ml}$

Volume of distillate and initial water transferred to J.P. Peterson:

Transfer Date:

Volume of distillate and water stored in-cell $\mathrm{ml}$

Remarks:

Voltage

$\underline{\text { Time }}$ 


\section{DISTRIBUTION}

Atomic Energy Commission San Francisco Operations Office 2111 Bancroft Way

Berkeley, California 94704

Arthur W. Larson

Site Representative

U.S. Atomic Energy Commission

c/o General Electric Company

310 DeGuigne Avenue

Sunnyvale, California 94086

U. S. Atomic Energy Commission Germantown, Maryland 20545

Attn: J.M. Simmons
A. Van Echo
J. A. Lieberman
S. A. Szawlewicz
M. A. Rosen
E. E. Kintner
D. E. Erb
W. H. McVey
I. F. Zartman
J. W. Vaughan
Document Library

U. S. Atomic Energy Commission

Chicago Operations Office

9800 South Cass Avenue

Argonne, lllinois

Attn: M.E. Jackson, Senior Site Representative, ANL

U. S. Atomic Energy Commissio

1

Post Office Box E

Oak Ridge, Tennessee 37830

Attn: D.F. Cope, Senior Site Representative, ORNL

U.S. Atomic Energy Commission

1

Richland Operations Office

Richland, Washington

Attn: P.G. Holsted, Senior Site Representative, PNL

U.S. Atomic Energy Commission 20

Department of Technical Information Extension

Oak Ridge Operations Office

P.O. Box E

Oak Ridge, Tennessee 37830

Attn: R. L. Shannon
U. S. Atomic Energy Commission Savannah River Operations Office P.O. Box 8

Aiken, South Carolina 29801

Attn: N. Stetson

Ames Laboratory

lowa State University

Box 1129 ISU Station

Ames, lowa 50010

Attn: F.H. Spedding

O. N. Carison

W. L. Larsen

1

1

1

Argonne National Laboratory

9700 South Cass Avenue

Argonne, Illinois 60440

Attn:

R. C. Vogel

M. V. Nevitt

J.H. Kittel

1

1

1

Brookhaven National Laboratory

Upton, New York 11973

Attn: D.H. Gurinsky

Los Alamos Scientific Laboratory

P.O. Box 1663

Los Alamos, New Mexico 87544

Attn:

D. E. Hall

R. D. Baker

1

1

Oak Ridge National Laboratory

Oak Ridge Operations Office

P.O. Box E

Oak Ridge, Tennessee 37830

Attn: J.E. Cunningham 2

P. Patriarca

D. E. Gerguson 1

J. R. Weir

Pacific Northwest Laboratory

P.O. Box 999

Richland, Washington 99352

Attn: F.W. Albaugh

J. J. Cadwell

A. L. Bement

R. L. Dillon

R. G. Wheeler

R. P. Marshall

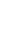

\section{(1)} 1 
Atomics International

P.0. Box 301

Canoga Park California 91304

Attn: $S_{\text {. Arneson }}$

Battelle Memorial Institute 505 King Avenue

Columbus, Ohio 43201

Attr:
S. Paprocki
D. Keller
W. Berry
DMIC

Babcock \& Wilcox Company

P.O. Box 1260

Lynchburg, Va. 24505

Attn:
C. Baroch
L. Weissert
J. Landis
C. Johnson

Combustion Engineering, Inc. Naval Reactors Division

P.O. Box 400

Windsor, Connecticut 06095

Attn: W. P. Chernock

S. S. Christopher

Gulf General Atomics, Inc.

P.O. Box 608

San Diego, California 92112

Attn: S. Jaye

General Electric Company

Knolis Atomic Power Laboratory

One River Road

Schenectady, N.Y.

Attn: A. E. Bibb

General Electric Company

Nuclear Systems Programs

P.O. Box 132

Cincinnati, Ohio 45215

Attn: V.P. Calkins

C. Brassfield

J. McGurty

Savannah River Laboratory-du Pont

E.l. du Pont de Nemours \& Co.

Savannah River Plant

Aiken, South Carolina 29801

Attn: TIS Document Room

1
Westinghouse Electric Corporation

APD

P.O. Box 355

Pittsburgh, Pa. 15230

Attn: T. Stern

Westinghouse Electric Corporation Bettis Atomic Power Plant

P.O. Box 79

West Mifflin, Pa. 15122

Attn: E. J. Kreigh

R. H. Fillnow

B. Lustman

W. J. Babyak

1

1

1

1

Idaho Nuclear Corporation

P.O. Box 1845

Idaho Falls, Idaho 83401

Attn: J.M. Beeston

W. C. Francis

1

1

United Nuclear Library

1

Grasslands Road

Elmsford, New York 10523 